\title{
PENGARUH KOMPETENSI TERHADAP KINERJA PEGAWAI PADA DINAS PERHUBUNGAN KABUPATEN SUBANG
}

\author{
Oleh : \\ Luki Natika \\ Fakultas ilmu Administrasi Universitas Subang \\ luckynatika@gmail.com
}

\begin{abstract}
ABSTRAK
Penelitian yang dilakukan ini bertujuan untuk mengetahui pengaruh kompetensi terhadap kinerja pegawai pada Dinas Perhubungan Kabupaten Subang. Latar belakang dari penelitian ini adalah kompetensi pegawai menjadi sesuatu yang dominan dalam suatu organisasi dan kinerja pegawai merupakan sesuatu yang berperan sangat penting dalam pencapaian tujuan organisasi. Penelitian ini merupakan jenis penelitian eksplanasi, yaitu penelitian dapat dikaji menurut tingkatannya yang didasarkan kepada tujuan dan obyekobyeknya. Populasi dalam penelitian ini adalah pegawai Dinas Perhubungan Kabupaten Subang, dengan jumlah sampel penelitian sebanyak 54 orang. Metode pengambilan sampel yaitu dengan menggunakan tehnik Proportionate Stratified Random Sampling. Metode pengumpulan data dalam penelitian ini adalah studi kepustakaan, observasi, wawancara dan kuesioner. Data diproses dengan menggunakan SPSS 16.0 for windows. Metode yang digunakan dalam penelitian ini adalah metode kuantitatif dengan maksud mencari pengaruh antara variabel $\mathrm{x}$ dan variabel $\mathrm{y}$.

Hasil dari penelitian ini adalah kompetensi mempunyai hubungan dengan kinerja pegawai dan besarnya tingkat korelasi yang diperoleh antara variabel kompetensi dengan kinerja sebesar 0.551 termasuk dalam tingkat hubungan sedang. Sedangkan berdasarkan hasil koefisien determinasi bahwa kinerja pegawai Dinas Perhubungan Kabupaten Subang dipengaruhi oleh kompetensi sebesar 30,4\% sedangkan sisanya 69,6\% dipengaruhi oleh faktor lain yang tidak diteliti dalam penelitian ini.
\end{abstract}

Kata kunci : Kompetensi dan Kinerja Pegawai

\begin{abstract}
This research aims to determine the effect on the performance of employees competence in Subang District Department of Transportation. The background of this research is the competence of the employees into something dominant in the organization and performance of employees is something very important role in the achievement of organizational goals. This research is explanatory research, that research can be assessed according to the level that is based on the goals and objects. The population in this study were employees subang District Department of Transportion the number of sample is 54 people. The sampling method is by using the proportionate stratified random sampling technique. Methods of data collection in this research is the study of literature, observation, interviews and questionnaires. The data is processed by using SPSS 16.0 for windows. The method used in this research is quantitative method with the intention of looking for influence between the variables $x$ and $y$ variables.
\end{abstract}

The results of this study are competency have a relationship with an employees performance and the level of correlation between variables obtained competency with the performance of 0,551, including the level of medium relationship. While based on the 
coefficient of determination that the District Department of Transportation employees performance subang influenced by the competence of 30,4\% while the remaining $69,9 \%$ is influenced by other factors not examined in this study.

Key word : Competency and Employee Performance

\section{PENDAHULUAN}

Pembangunan di sektor perhubungan atau transportasi merupakan salah satu untuk meningkatkan pembangunan ekonomi yang antara lain mencakup aktivitas perdagangan, industri atau aktivitas dari sistem transportasi lainnya. Hal ini bertolak dari pandangan para ahli bahwa sektor perhubungan atau transportasi pada umumnya mempunyai hubungan korelasi yang positif dengan pembangunan ekonomi, sehingga semakin maju tingkat perekonomian suatu negara, tuntutan akan kebutuhan jasa perhubungan atau transportasi akan semakin besar pula. Keberhasilan pembangunan di saat ini dan di masa yang akan datang, peran sektor perhubungan akan sangat menentukan. Terhadap peran tersebut baik fungsinya sebagai unsur penunjang pembangunan maupun pemberi jasa bagi perkembangan ekonomi, peranan transportasi tidak hanya memperlancar arus barang dan mobilitas manusia tetapi juga membantu tercapainya pengalokasian sumber-sumber ekonomi secara optimal. Untuk itu, jasa transportasi harus baik dan cukup tersedia secara merata. Pembangunan sektor perhubungan yang maju bisa menjadi daya tarik bagi para investor untuk menanamkan modalnya pada daerah-daerah yang belum maju atau sedang berkembang. Infrastruktur transportasi dapat difungsikan secara aktif untuk menggerakkan perekonomian daerah yang didahului dengan pembangunan infrastruktur transportasi berupa jalan raya yang memadai dan layak, yang artinya pembangunan infrastruktur jalan, kebijakan diarahkan pada pembangunan jalan baru atau pembuatan jalan inter koneksi. Juga difokuskan pada pemeliharaan, perbaikan dan peningkatan jalan yang sudah ada.
Dengan adanya infrastruktur transportasi, kegiatan-kegiatan sektor ekonomi lainnya akan tumbuh dan berkembang dengan sendirinya (trade follows the ship). Pembangunan infrastruktur transportasi dengan tujuan seperti ini, dilakukan dalam rangka pembangunan wilayah atau daerahdaerah terpencil, dimana kegiatan ekonomi dan perdagangan belum berjalan dengan baik.

Pada wilayah atau daerah-daerah dimana kegitan-kegiatan sektor perekonomian sudah berjalan, infrastruktur transportasi berfungsi sebagai roda penggerak perekonomian (ship follows the trade). Pembangunan infrastruktur transportasi di daerah ini diarahkan untuk menambah kapasitas transportasi dalam mendukung pertumbuhan dan perkembangan sektor-sektor ekonomi. Infrastruktur transportasi dalam fungsinya sebagai fasilitas publik memberikan pelayanan publik bagi masyarakat yaitu : (1) Mendorong pemerataan pembangunan;

(2) Melayani kebutuhan pergerakan masyarakat dengan harga yang terjangkau; (3) Memperlancar mobilitas distribusi barang dan jasa; (4) Mendorong pertumbuhan sektor ekonomi lainnya. Dalam kaitannya dengan pertumbuhan sektor ekonomi lainnya, infrastruktur transportasi menghubungkan berbagai macam aktivitas ekonomi, yang merupakan prasarana penghubung antar daerah dan memudahkan mobilitas penduduk serta memperlancar lalu lintas barang antar daerah maupun pengiriman barang ke luar negeri. Memperhatikan berbagai fungsi dan manfaat infrastuktur transportasi tersebut, pembangunan infrastruktur transportasi harus diarahkan untuk meningkatkan pelayanan jasa transportasi yang efektif, efisien, berkualitas, aman, nyaman dan 
dengan harga yang terjangkau oleh masyarakat. Oleh karena itu dalam mencapai terselenggaranya pembangunan di sektor perhubungan yang maju, dibutuhkan sumberdaya manusia yang handal dan berkompentensi dibidangnya pada instansi dinas perhubungan.

Demi terselenggaranya

pembangunan infrastuktur transportasi tersebut maka dibutuhkan sumber daya manusia yang tepat dalam tata kelola dan perencanaan dalam pembangunannya. Sumber daya manusia merupakan sumber daya terpenting dalam suatu organisasi dimana orang-orang tersebut memberikan tenaga, bakat, kreativitas, dan usaha mereka kepada organisasi demi tercapainya tujuan organisasi. Oleh karena itu, sumber daya manusia merupakan salah satu faktor penentu keberhasilan dalam suatu organisasi karena sumber daya manusia memberikan kontribusi terbesar dibandingkan dengan sumber daya yang lainnya. Untuk mendapatkan sumber daya manusia yang tepat, handal dan kompeten dibidangnya, maka bagian sumber daya manusia dalam suatu organisasi harus mampu mengadakan dari awal proses rekruitmen pegawai secara selektif yang ketat dan profesionalisme supaya kinerja yang dihasilkan pun akan maksimal. Berkaitan dengan hal tersebut, banyak sekali faktor yang dapat berhubungan dengan kinerja seorang pegawai, salah satunya adalah faktor kompetensi. Dalam hal ini adalah seorang pegawai harus mampu dalam menumbuhkembangkan seluruh potensi yang terbaik yang dimiliki dalam dirinya. Seorang pegawai akan berkembang dan mampu bertahan dalam lingkungan persaingan yang kompetitif apabila didukung oleh pegawai-pegawai yang berkompeten dibidangnya. Kompetensi sangat berguna untuk membantu organisasi menciptakan budaya kinerja tinggi. Kompetensi sangat diperlukan dalam setiap proses perkembangan sumber daya manusia, seleksi karyawan, manajemen kinerja, perencanaan dan sebagainya. Semakin banyak kompetensi dipertimbangkan dalam proses sumber daya manusia, maka akan semakin meningkatkan kinerja pegawai dan juga budaya organisasi. Demikian pula diperlukan untuk mengkomunikasikan nilai dan standar organisasi, menganalisis dan memperbaiki kinerja pegawai dan budaya organisasi, menyeleksi, dan merekrut pegawai, menilai dan mengembangkan pegawai, mengembangkan pemimpin, mengelola proses perencanaan, membangun dasar untuk strategi pelatihan, dan membentuk proses kompetensi.

Hakikatnya kinerja merupakan hasil kerja yang dicapai oleh seseorang dalam melaksanakan tugasnya sesuai dengan standar dan kriteria yang ditetapkan untuk pekerjaan tersebut. Kinerja merupakan salah satu kumpulan total dari kerja yang ada pada diri seorang pegawai atau tugas yang diberikan. Kinerja merupakan suatu fungsi dari motivasi dan kemampuan untuk menyelesaikan tugas dan pekerjaan, seorang pegawai harus memiliki derajat kesediaan dan tingkat kemampuan. Kinerja merujuk pada tingkat keberhasilan dalam melaksanakan tugas serta kemampuan untuk mencapai tujuan yang telah ditetapkan. Jika tujuan yang diinginkan dapat tercapai dengan baik, maka kinerja dinyatakan baik dan sukses. Untuk itu dalam pencapaian tujuan kinerja maka akan berhubungan dengan sumber daya manusia, kompetensi, kemampuan dan motivasi kerja. Tingkat kinerja pegawai pemerintah secara umum belum mencapai standar profesionalisme. Hal ini dibuktikan dengan masih rendahnya tingkat kehadiran pegawai, pimpinan tidak berada di tempat, sirkulasi surat keluar masuk yang kurang di tanggapi kecuali ada uang pelicin proses berkas cepat, pelayanan terhadap publik yang masih sering mendapat keluhan, banyak pegawai pemerintah datang ke kantor sesukanya, mengisi absen, mengobrol dan pulang, pencitraan baik ketika ada pengawas/pimpinan dari pusat, bahkan di saat jam kerja ada pegawai yang berbelanja di pasar atau di mal. Pegawaipegawai seperti itu tingkat kinerjanya 
sangat rendah, sehingga pelayanan publik pun tidak terselenggara dengan baik atau tidak maksimal. Permasalahan seperti itu hampir terjadi di seluruh instansi pemerintahan di Indonesia, tidak terkecuali pada Dinas Perhubungan Kabupaten Subang. Untuk itu dalam rangka menjalankan tugas umum pemerintahan dan pembangunan, dituntut adanya kemampuan dan kemahiran manajerial yang dapat mengintegrasikan dan mengarahkan seluruh sumber daya kepada pencapaian tugas pokok, sasaran, visi dan misi organisasi, disamping itu dituntut pula pengetahuan dan keterampilan teknis yang memungkinkan mutu hasil pelaksanaan organisasi sesuai dengan yang diharapkan.

Dinas Perhubungan Kabupaten Subang yang merupakan salah satu dinas yang menjadi penyumbang pendapatan asli daerah belum bisa memberikan kontribusi besar dalam hal pelayanan publik, sehingga masyarakat bertanya-tanya kemana digunakan setiap dana yang jumlahnya yang sangat besar dari setiap pungutan retribusi dan lain sebagainya. Munculnya stigma seperti itu dalam masyarakat subang bukan hanya pemikirin masyarakat awam di kabupaten subang saja akan tetapi terbentuk karena belum maksimalnya dari pelayanan publik yang dilakukan oleh Dinas Perhubungan Kabupaten Subang.

Hasil penelitian pada dinas perhubungan kabupaten Subang masih terdapat permasalahan yang berupa kinerja pegawai masih rendah, antara lain :

1. Berdasarkan penelitian pada Dinas Perhubungan Kabupaten Subang masih rendahnya kompetensi pengetahuan pegawai, hal ini sesuai laporan indikator kegiatan Dinas Perhubungan Kabupaten Subang tahun 2009 - 2014, Target pencapaian yang dianggarkan untuk sasaran kegiatan pendidikan dan pelatihan formal tiap tahunnya hanya sebesar $2 \%$ berbeda dengan sasaran kegiatan pemeliharan rutin gedung tiap tahunnya target pencapaiannya sebesar $5 \%$ dan pengadaan kendaraan dinas sebesar $10 \%$, padahal kita mengetahui kegiatan pendidikan dan pelatihan sangat berguna untuk menghasilkan pegawai-pegawai yang handal,terampil dan kompeten dibidang.

2. Berdasarkan penelitian pada Dinas Perhubungan Kabupaten Subang masih rendahnya kualitas kerja pegawai, hal ini sesuai dengan realitas dilapangan terjadi pelanggaran Perda no.21 Tahun 2001 Provinsi Jawa Barat tentang daya dukung jalan di jawa barat yang rata-rata 8 ton, dimana armada pengangkut air minum dalam kemasan PT Tirta Investama (aqua Subang) yang sudah jelas bobot muatannya melebihi tonase, yang mencapai rata-rata 12 ton.

3. Berdasarkan penelitian pada Dinas Perhubungan Kabupaten Subang masih rendahnya tanggungjawab kerja pegawai, hal ini sesuai dalam pelaksanaan pengujian kendaraan bermotor tidak melakukan lagi pemeriksaan fisik kendaraan bermotor bahkan terkesan lebih mengutamakan penerimaan PAD.

\section{METODE}

Dari fokus masalah dan tujuan penelitian yang dipaparkan sebelumnya, maka penelitian ini diarahkan untuk mengungkapkan secara mendalam bagaimana pengaruh kompetensi terhadap kinerja pegawai pada Dinas Perhubungan Kabupaten Subang, oleh karena itu metode yang digunakan dalam penelitian ini adalah dengan pendekatan kuantitatif yaitu penelitian yang data-datanya berupa angkaangka atau data-data yang diangkakan (Sugiyono,2007: 22). Sedangkan Jenis penelitian yang dilakukan adalah penelitian asosiatif dengan analisa kuantitatif, dengan maksud untuk mencari maksud dan pengaruh antara variabel independen (X) 
dengan variabel dependen (Y) yang menggunakan statistik (Arikunto,1996: 5).

Pendekatan penelitian yang dilakukan ini melalui beberapa tahapan, yakni diawali dengan mengumpulkan data melalui penyebaran kuesioner kepada sejumlah responden yang menjadi sampel penelitian kemudian menganalisis data yang sudah terkumpul dan disajikan dalam bentuk skripsi.

$$
\text { Populasi adalah wilayah }
$$

generalisasi yang terdiri atas obyek/subyek yang mempunyai kualitas dan karakteristik tertentu yang ditetapkan oleh peneliti untuk dipelajari dan kemudian ditarik kesimpulannya (Sugiyono,2007: 90). Dalam penelitian ini yang menjadi populasi adalah seluruh pegawai Dinas Perhubungan Kabupaten Subang yang berjumlah 118 orang. Dalam penelitian ini untuk menentukan jumlah sampel yang representative penulis menggunakan teknik penarikan sampel berdasarkan rumus Slovin ( Prasetyo,2005: 136) yakni sebagai berikut:

Keterangan:

$$
\mathrm{n}=\frac{N}{1+N e^{2}}
$$

$\mathrm{n}$ : jumlah sampel

$\mathrm{N}$ : jumlah populasi

e : presisi ditetapkan $10 \%$ dengan tingkat kepercayaan $90 \%$.

Dari rumus tersebut, maka di ambil sampel dengan jumlah:

$$
\begin{aligned}
& \mathrm{n}=\frac{118}{1+118(0,1)^{2}} \\
& \mathrm{n}=\frac{118}{2,18} \\
& \mathrm{n}=54,12
\end{aligned}
$$

Hasil jumlah sampel yang didapat tersebut $(54,12)$. Maka jumlah pegawai yang dijadikan sampel adalah sebanyak 54 orang.

Adapun teknik yang digunakan
dalam menentukan sampel yaitu
Proportionate Stratified Random Sampling, Teknik ini hampir sama dengan simple random sampling namun penentuan sampelnya memperhatikan strata (tingkatan) yang ada dalam populasi. Teknik ini digunakan karena pada populasi yang diteliti adalah heterogen (tidak sejenis) yang dalam hal ini berbeda dalam hal tingkat pendidikannya sehingga besaran sampel pada masing-masing strata atau kelompok diambil secara proporsional. Dengan rumus Slovin dan tingkat kesalahan $10 \%$ diperoleh besar sampel adalah 54 .

\section{HASIL DAN PEMBAHASAN}

Uji Validitas sangat diperlukan dalam suatu penelitian, khususnya yang menggunakan kuesioner. Dalam data, uji validitas dimaksudkan untuk mengetahui keabsahan menyangkut pemahaman antara konsep dengan kenyataan empiris. cara pengujian validitas konstruk yaitu dengan menghitung korelasi antara masing-masing pertanyaan dengan skor faktor dengan menggunakan teknik korelasi (r) Product Moment. Kriteria pengujian untuk menerima atau menolak hipotesis dengan adanya pertanyaan yang valid atau tidak, dapat dilakukan dengan: Apabila koefisien korelasi yang diperoleh lebih besar dari atau sama dengan nilai r-kritis yaitu sebesar 0,3 maka dapat dinyatakan bahwa instrumen yang digunakan valid. Dalam penelitian ini, penulis melakukan pengujian dengan menggunakan Statistical Programming for Social Science (SPSS) versi 16 . Pengujian validitas instrument instrumen ini dilakukan pada 20 responden. Setelah ditemukan adanya pernyataan pada instrumen yang secara statistik tidak memenuhi persyaratan untuk valid, maka penulis memperbaiki kalimat pernyataan tersebut dan kuesioner disebar ulang atau mengulangi pengisian kuesioner serta uji validitas hingga data itu menjadi valid sesuai dengan ketentuan. Adapun hasil validitas antar butir atas instrumen tersebut dapat dilihat pada tabel di bawah ini : 
HASIL PENGUJIAN VALIDITAS VARIABEL X

\begin{tabular}{|c|c|c|c|}
\hline Pernyataan & $\begin{array}{c}\text { Korelasi antar } \\
\text { Butir }\end{array}$ & $\mathrm{r}$ Kritis & Kesimpulan \\
\hline 1 & 0.807 & 0.3 & Valid \\
\hline 2 & 0.757 & 0.3 & Valid \\
\hline 3 & 0.807 & 0.3 & Valid \\
\hline 4 & 0.707 & 0.3 & Valid \\
\hline 5 & 0.379 & 0.3 & Valid \\
\hline 6 & 0.807 & 0.3 & Valid \\
\hline 7 & 0.807 & 0.3 & Valid \\
\hline 8 & 0.886 & 0.3 & Valid \\
\hline 9 & 0.680 & 0.3 & Valid \\
\hline 10 & 0.532 & 0.3 & Valid \\
\hline 11 & 0.403 & 0.3 & Valid \\
\hline 12 & 0.359 & 0.3 & Valid \\
\hline 13 & 0.620 & 0.3 & Valid \\
\hline 14 & 0.886 & 0.3 & Valid \\
\hline 15 & 0.560 & 0.3 & Valid \\
\hline 16 & 0.619 & 0.3 & Valid \\
\hline 17 & 0.459 & 0.3 & Valid \\
\hline 18 & 0.392 & 0.3 & Valid \\
\hline 19 & 0.596 & 0.3 & Valid \\
\hline
\end{tabular}

Berdasarkan tabel diatas, dapat diketahui bahwa seluruh pernyataan telah valid. Karena seluruh pernyataan memiliki nilai koefisien korelasi atau nilai $r$ lebih dari 0.3 , dari pernyataan diatas diperoleh pernyataan ke 8 dan 14 memperoleh nilai validitas tertinggi dengan koefisien korelasi sebesar 0.886. Sedangkan validitas terendah terdapat pada pernyataan ke 12 dengan nilai korelasi sebesar 0.359 . Hasil pengujian tersebut mengindikasikan instrumen variabel $\mathrm{X}$ dinyatakan semuanya valid. Oleh karena itu data dari instrumen tersebut dapat dianalisis lebih lanjut.

Pengujian selanjutnya dilakukan pada variabel $Y$ yaitu kinerja pegawai Dinas Perhubungan Kabupaten Subang. Adapun hasil validitas antar butir atas variabel Y tersebut dapat dilihat pada tabel di bawah ini :

HASIL PENGUJIAN VALIDITAS VARIABEL Y

\begin{tabular}{|c|c|c|c|}
\hline Pernyataan & $\begin{array}{c}\text { Korelasi antar } \\
\text { Butir }\end{array}$ & r Kritis & Kesimpulan \\
\hline 1 & 0.416 & 0.3 & Valid \\
\hline 2 & 0.665 & 0.3 & Valid \\
\hline 3 & 0.434 & 0.3 & Valid \\
\hline 4 & 0.480 & 0.3 & Valid \\
\hline 5 & 0.820 & 0.3 & Valid \\
\hline 6 & 0.945 & 0.3 & Valid \\
\hline 7 & 0.915 & 0.3 & Valid \\
\hline 8 & 0.587 & 0.3 & Valid \\
\hline 9 & 0.736 & 0.3 & Valid \\
\hline 10 & 0.863 & 0.3 & Valid \\
\hline
\end{tabular}




\begin{tabular}{|l|l|l|l|}
11 & 0.754 & 0.3 & Valid \\
\hline 12 & 0.675 & 0.3 & Valid \\
\hline 13 & 0.611 & 0.3 & Valid \\
\hline 14 & 0.571 & 0.3 & Valid \\
\hline 15 & 0.318 & 0.3 & Valid \\
\hline 16 & 0.694 & 0.3 & Valid \\
\hline 17 & 0.355 & 0.3 & Valid \\
\hline 18 & 0.717 & 0.3 & Valid \\
\hline 19 & 0.694 & 0.3 & Valid \\
\hline 20 & 0.495 & 0.3 & Valid \\
\hline
\end{tabular}

Berdasarkan tabel diatas, dapat diketahui bahwa seluruh pernyataan dari variabel Y dinyatakan valid, karena seluruh pernyataan memiliki nilai koefisien atau nilai $r$ yang diperoleh lebih besar dari 0.3. Validitas pernyataan tertinggi terdapat pada pernyataan ke 6 dengan nilai koefisien sebesar 0.945, sedangkan validitas pernyataan terendah terdapat pada pernyataan ke 15 dengan nilai koefisien korelasi sebesar 0.318. Hasil pengujian tersebut mengindikasikan instrumen variabel $\mathrm{Y}$ dinyatakan semuanya valid. Oleh karena itu data dari instrumen tersebut dapat dianalisis lebih lanjut.

\section{Uji Reliabilitas}

Dalam penelitian ini uji reliabilitas dilakukan dengan menggunakan rumus Alpha-Cronbach's guna mengetahui apakah hasil pengukuran data yang diperoleh memenuhi syarat reliabilitas. Instrumen kuesioner dapat dikatakan reliabel bila memiliki koefisien alpha sebesar lebih dari angka 0,6.

Berdasarkan hasil pengujian dengan Statistical Programming for Social Science (SPSS) versi 16. Untuk variabel $\mathrm{X}$ dan $\mathrm{Y}$, maka hasil pengujian dapat dilihat dari tabel dibawah ini :

\section{HASIL PENGUJIAN RELIABILITAS \\ VARIABEL $X$}

\section{Case Processing Summary}

\begin{tabular}{|c|c|c|c|}
\hline & & $\mathrm{N}$ & $\%$ \\
\hline \multirow[t]{3}{*}{ Cases } & Valid & 20 & 100.0 \\
\hline & Excludeda & 0 & .0 \\
\hline & Total & 20 & 100.0 \\
\hline
\end{tabular}

a. Listwise deletion based on all variables in the procedure.

Reliability Statistics

\begin{tabular}{|r|r|}
\hline Cronbach's Alpha & \multicolumn{2}{|c|}{ N of Items } \\
\hline .859 & 19 \\
\hline
\end{tabular}

Tabel 4.4 


\section{HASIL PENGUJIAN RELIABILITAS \\ VARIABEL Y}

Case Processing Summary

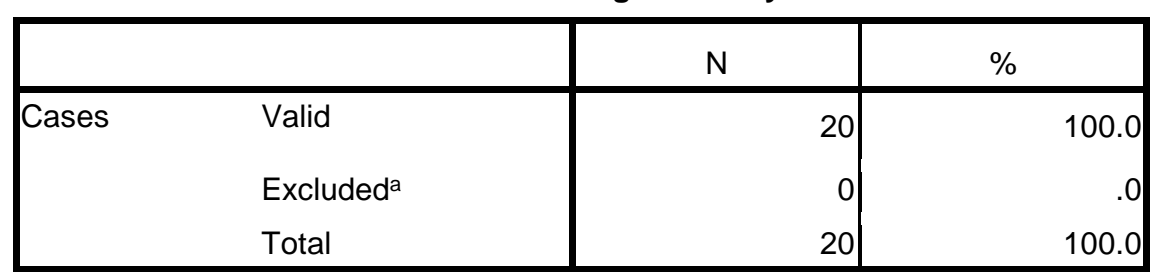

a. Listwise deletion based on all variables in the procedure.

Reliability Statistics

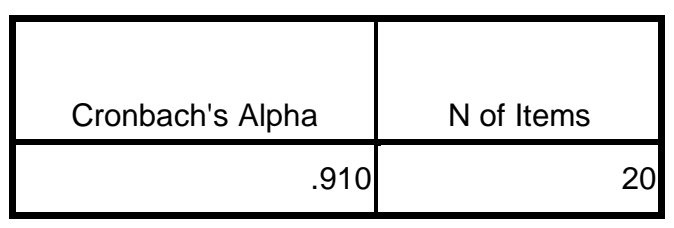

Berdasarkan tabel di atas, menunjukkan bahwa variabel $\mathrm{X}$ memiliki nilai Cronbach alpha 0.859 dan variabel Y dengan nilai Cronbach alpha sebesar 0.910 dari item penyataan sebanyak 19 pernyataan untuk variabel $X$ dan variabel $Y$ sebanyak 20 item pernyataan, maka dapat dijelaskan bahwa angka tersebut dapat dikatakan reliabel karena nilai Cronbach alpha yang diperoleh variabel $\mathrm{X}$ dan $\mathrm{Y}$ lebih dari 0,6. Dengan demikian hasil penelitian instrumen tersebut sudah layak dan dapat digunakan untuk menghimpun data.

\section{Pengujian Hubungan (Asosiatif)}

Untuk melihat ada atau tidak adanya hubungan kompetensi dengan kinerja pegawai Dinas Perhubungan Kabupaten Subang, maka sebelumnya telah diajukan hipotesis penelitian sebagai berikut : "Terdapat pengaruh kompetensi terhadap kinerja pegawai pada Dinas Perhubungan Kabupaten Subang".

Pengujian hubungan antara kompetensi dengan kinerja pegawai Dinas Perhubungan Kabupaten Subang, berdasarkan hasil pengujian dengan Statistical Programming for Social Science (SPSS) versi 16 dan menggunakan rumus koefisien korelasi. Statistik uji ini dipilih berdasarkan bentuk data diolah adalah berskala ordinal.

Untuk menghitung korelasi antar variabel kompetensi dengan kinerja pegawai Dinas Perhubungan Kabupaten Subang adalah dengan menggunakan metode Statistical Programming for Social Science (SPSS) versi 16. Adapun hasilnya sebagai berikut :

Hasil Pengujian korelasi

\begin{tabular}{|l|r|r|r|}
\hline & \multicolumn{1}{|c|}{ Descriptive Statistics } \\
\hline & Mean & Std. Deviation & \multicolumn{1}{|c|}{$\mathrm{N}$} \\
\hline Keinerja & 56.59 & 11.667 & 54 \\
kompetensi & 55.67 & 7.284 & 54 \\
\hline
\end{tabular}




\begin{tabular}{|ll|r|r|}
\hline \multicolumn{3}{|c|}{ Correlations } \\
\hline Pearson Correlation & keinerja & kompetensi \\
& komerja & 1.000 & .551 \\
& kompetensi & .551 & 1.000 \\
\hline Sig. (1-tailed) & keinerja &. & .000 \\
& kompetensi & .000 & \\
\hline $\mathrm{N}$ & keinerja & 54 & 54 \\
& kompetensi & 54 & 54 \\
\hline
\end{tabular}

Berdasarkan hasil penghitungan Statistical Programming for Social Science (SPSS) versi 16 tersebut maka dapat disimpulkan bahwa hubungan antar variabel kompetensi dengan kinerja pegawai Dinas Perhubungan Kabupaten Subang adalah "sedang" dengan nilai sebesar 0.551. Sebagaimana yang dikemukakan oleh Sugiyono (2007: 214), nilai tersebut berada pada interval koefisien $0.40-0.599$.

\section{Analisis Regresi Sederhana}

Analisis regresi digunakan untuk melihat pengaruh kompetensi terhadap kinerja pegawai Dinas Perhubungan Kabupaten Subang. Dengan demikian dapat diketahui persamaan regresi dengan menggunakan bantuan metode Statistical Programming for Social Science (SPSS) versi 16. Hasil olahan data tersebut dirangkum dalam tabel dibawah berikut ini :

Analisis Regresi Sederhana

\begin{tabular}{|c|c|c|c|c|c|c|}
\hline \multicolumn{7}{|c|}{ Coefficients $^{a}$} \\
\hline \multirow{2}{*}{\multicolumn{2}{|c|}{ Model }} & \multicolumn{2}{|c|}{ Unstandardized Coefficients } & $\begin{array}{l}\text { Standardized } \\
\text { Coefficients }\end{array}$ & \multirow[b]{2}{*}{$\mathrm{t}$} & \multirow[b]{2}{*}{ Sig. } \\
\hline & & B & Std. Error & Beta & & \\
\hline 1 & (Constant) & 7.432 & 10.405 & & .714 & .478 \\
\hline & kompetensi & .883 & .185 & .551 & 4.763 & .000 \\
\hline
\end{tabular}

a. Dependent Variable: keinerja

Berdasarkan tabel diatas, di dapat pada kolom B pada Constant (a) adalah 7,432, sedang nilai kompetensi (b) adalah 0,883 , sehingga persamaan regresi antara kompetensi terhadap kinerja pegawai Dinas Perhubungan Kabupaten Subang dapat disusun sebagai berikut :

$$
\begin{aligned}
& Y=a+b X \\
& Y=7,432+0,883
\end{aligned}
$$

Koefisien b dinamakan keofisien arah regresi dan menyatakan perubahan rata-rata variabel $\mathrm{Y}$ untuk setiap perubahan variabel $X$ sebesar satu satuan. Perubahan ini merupakan pertambahan bila $\mathrm{b}$ bertanda positif dan penurunan bila $b$ bertanda negatif. Sehingga dari persamaan tersebut dapat diterjemahkan :

- Konstanta sebesar 7,432 menyatakan bahwa jika tidak ada nilai kompetensi (X), maka nilai kinerja pegawai Dinas Perhubungan Kabupaten Subang (Y) akan mencapai nilai sebesar 7,432.

- Koefisien regresi X sebesar 0,883 menyatakan bahwa setiap penambahan atau peningkatan satusatuan variabel X (kompetensi), maka akan bertambah/meningkatkan kinerja sebesar 0,883 . 


\section{Uji Regresi Sederhana}

Pengujian regresi sederhana ini digunakan untuk mengetahui sejauh mana tingkat signifikasi pengaruh variabel kompetensi terhadap variabel kinerja pegawai Dinas Perhubungan Kabupaten Subang. Sehingga dapat diperoleh informasi mengenai variabel mana yang memiliki pengaruh yang paling dominan. Dari hasil perhitungan dengan menggunakan metode Statistical Programming for Social Science (SPSS) versi 16 , diperoleh nilai $t_{h i t u n g}$ yang ditunjukan pada tabel dibawah ini :

Uji Regresi Sederhana

\begin{tabular}{|c|c|c|c|c|c|c|}
\hline \multicolumn{7}{|c|}{ Coefficients $^{a}$} \\
\hline \multirow{2}{*}{\multicolumn{2}{|c|}{ Model }} & \multicolumn{2}{|c|}{ Unstandardized Coefficients } & \multirow{2}{*}{$\begin{array}{c}\text { Standardized } \\
\text { Coefficients }\end{array}$} & \multirow[b]{2}{*}{$\mathrm{t}$} & \multirow[b]{2}{*}{ Sig. } \\
\hline & & $\mathrm{B}$ & Std. Error & & & \\
\hline \multirow[t]{2}{*}{1} & (Constant) & 7.432 & 10.405 & & .714 & .478 \\
\hline & kompetensi & .883 & .185 & .551 & 4.763 & .000 \\
\hline
\end{tabular}

a. Dependent Variable: keinerja

Berdasarkan tabel diatas, untuk mengetahui apakah ada pengaruh antara kompetensi dengan kinerja pegawai Dinas Perhubungan Kabupaten Subang, maka dapat dilakukan langkah-langkah sebagai berikut:

a. Terlebih dahulu kita tentukan hipotesisnya.

H0 : Tidak ada pengaruh positif antara kompetensi terhadap kinerja pegawai Dinas Perhubunga Kabupaten Subang.

H1 : Ada pengaruh positif antara kompetensi dengan kinerja pegawai Dinas Perhubungan Kabupaten Subang.

b. Menghitung besarnya angka $t$ penelitian.

Hasil perhitungan SPSS diperoleh $t$ penelitian sebesar 4.763.

c. Menghitung besarnya $t$ tabel.

Untuk mengetahui $t_{\text {tabel }}$ dengan $\mathrm{df}$ (derajat kebebasan $)=n-2$, yaitu 54 $-2=52$. Yang mendekati untuk df $=52$ adalah 60. Sehingga diperoleh $\mathrm{t}_{\text {tabel }}$ sebesar 1.671.

d. Untuk menguji hipotesisnya dapat menggunakan kriteria sebagai berikut :
- Jika $t$ penelitian $>t$ tabel maka $\mathrm{H} 0$ ditolak dan $\mathrm{H} 1$ diterima.

- Jika $t$ penelitian $<t$ tabel maka H0 diterima dan $\mathrm{H} 1$ ditolak.

Berdasarkan hasil perhitungan diperoleh angka $t$ penelitian sebesar 4.763 $>t$ tabel sebesar 1,671 maka $\mathrm{H} 0$ ditolak dan H1 diterima, yang berarti bahwa Ada pengaruh positif antara kompetensi dengan kinerja pegawai Dinas Perhubungan Kabupaten Subang. Besarnya pengaruh kompetensi terhadap kinerja pegawai sebesar 0.551 atau $55.1 \%$ dianggap signifikan. Hal ini juga tercermin juga pada angka signifikasi/probabilitas sebesar 0.000 yang lebih kecil dari 0.05 atau 0.000 $<\alpha$ (0.05), yang menunjukkan bahwa kompetensi berpengaruh secara signifikan terhadap kinerja pegawai.

\section{Analisis Koefisien Determinasi}

Setelah koefisien regresi sudah diketahui dan sudah diuji signifikannya, maka selanjutnya harus dihitung koefisien determinasi untuk mengetahui besarnya pengaruh kompetensi terhadap kinerja pegawai Dinas Perhubungan Kabupaten Subang. Adapun koefisien determinasi penelitian ini dapat dihitung dengan menggunakan metode Statistical 
Programming for Social Science (SPSS) versi 16. Untuk melihat hasil perhitungan koefisien determinasinya dapat dilihat pada tabel dibawah ini :

Koefisien Determinasi

Model Summaryb

\begin{tabular}{|l|r|r|r|r|}
\hline Model & $\mathrm{R}$ & R Square & \multicolumn{1}{|c|}{$\begin{array}{c}\text { Adjusted R } \\
\text { Square }\end{array}$} & $\begin{array}{l}\text { Std. Error of the } \\
\text { Estimate }\end{array}$ \\
\hline 1 & $.551^{\mathrm{a}}$ & .304 & .290 & 9.828 \\
\hline
\end{tabular}

a. Predictors: (Constant), kompetensi

b. Dependent Variable: keinerja

Berdasarkan hasil perhitungan diatas, dapat diketahui bahwa koefisien determinasi ( $\mathrm{R}$ square) adalah 0.304, dimana nilai determinasi ini artinya bahwa kinerja pegawai Dinas Perhubungan Kabupaten Subang dipengaruhi oleh kompetensi adalah sebesar 30,4\%. Adapun sisanya sebesar $69,6 \%$ dipengaruhi oleh faktor lain yang tidak diteliti pada penelitian ini.
Untuk mengetahui apakah model regresi di atas sudah benar atau salah maka diperlukan uji hipotesis. Uji hipotesis tersebut dengan melihat pada angka $\mathrm{F}$ dan juga angka signifikasinya dari tabel ANOVA, sebagaimana terlihat pada tabel di bawah ini :

\begin{tabular}{|ll|r|r|r|r|r|}
\hline Model & & Sum of Squares & df & Mean Square & F & Sig. \\
\hline 1 & Regression & 2191.758 & 1 & 2191.758 & 22.690 & $.000^{\mathrm{a}}$ \\
& Residual & 5022.996 & 52 & 96.596 & & \\
& Total & 7214.754 & 53 & & & \\
\end{tabular}

a. Predictors: (Constant), kompetensi

b. Dependent Variable: keinerja

Berdasarkan tabel diatas terlebih dahulu membuat hipotesisnya adalah sebagai berikut :

HO : Tidak ada pengaruh positif antara variabel kompetensi terhadap kinerja pegawai.

H1 : Ada pengaruh positif antara variabel kompetensi terhadap kinerja pegawai.

Pengujian hipotesis di atas dapat dilakukan dengan dua cara. Uji pertama dengan membandingkan angka $F$ penelitian dengan $\mathrm{F}$ tabel. Yang kedua adalah dengan cara membandingkan angka taraf signifikansi hasil perhitungan dengan taraf signifikasnsi $0.05 \%$.
1. Uji dengan membandingkan angka $F$ penelitian dengan $F$ tabel. Dimana diketahui bahwa :

a. F penelitian sebesar 22,690.

b. nilai $F$ tabel dapat diperoleh dengan menggunakan tabel $\mathrm{F}$ dengan derajat bebas (df) Residual sisa yaitu sebagai 52 df penyebut dan df regression (perlakuan) yaitu 1 sebagai df pembilang dengan taraf signifikan $0,05, \quad$ sehingga diperoleh nilai $\mathrm{F}$ tabel yaitu 4,03 (lebih dekat dengan df penyebut $50)$. 
c. Menentukan kriteria uji hipotesa sebagai berikut.

- Jika F penelitian > F tabel maka $\mathrm{H} 0$ ditolak dan $\mathrm{H} 1$ diterima.

- Jika F penelitian < F tabel maka $\mathrm{H} 0$ diterima dan $\mathrm{H} 1$ ditolak.

Mengambil keputusan dari pemaparan di atas dapat ditafsirkan bahwa dari hasil perhitungan didapatkan $\mathrm{F}$ penelitian sebesar 22,690 > F tabel sebesar 4,03. Maka H0 ditolak dan $\mathrm{H} 1$ diterima yang artinya bahwa ada pengaruh positif antara variabel kompetensi terhadap kinerja pegawai Dinas Perhubungan Kabupaten Subang.

2. Membandingkan angka signifikansi penelitian dengan taraf signifikansi 0,05 atau 5\%. Uji hipotesisnya dengan menggunakan kriteria sebagai berikut:

Hasil Uji Normalitas
- Jika signifikansi penelitian > $0.05 \%$ maka $\mathrm{H} 0$ diterima dan $\mathrm{H} 1$ ditolak.

- Jika signifikansi $<0.05 \%$ maka H0 ditolak dan H1 diterima.

Berdasarkan pada hasil perhitungan di atas menunjukkan angka signikansi sebesar $0,000<0,05 \%$ maka $\mathrm{H} 0$ ditolak dan $\mathrm{H} 1$ diterima, yang berarti bahwa pengaruh antara variabel kompetensi terhadap kinerja pegawai pada Dinas Perhubungan Kabupaten Subang cukup signifikan.

\section{Uji Normalitas Data}

Uji normalitas data dilakukan untuk mengetahui apakah data yang dijadikan bahan untuk penelitian berdistribusi normal apa tidak. Berikut gambar hasil uji normalitas data yang diperoleh dari hasil penghitungan dengan menggunakan Statistical Programming for Social Science (SPSS) versi 16.

\section{Normal P-P Plot of Regression Standardized Residual}

Dependent Variable: keinerja

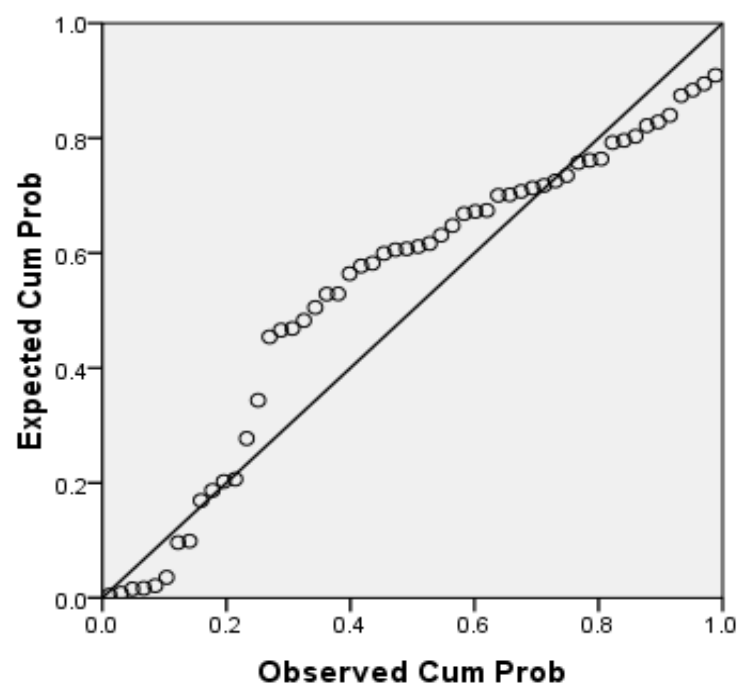

Berdasarkan gambar diatas, dapat diketahui bahwa bersifat homogen dan terdistribusi normal. Hal tersebut berarti data yang ada layak untuk dijadikan penelitian. Mengingat bahwa dalam statistik parametris mengisyaratkan data pada setiap variabel yang akan dianalisis harus berdistribusi normal, maka dilakukan uji normalitas data tersebut. 


\section{Deskripsi Variabel Kompetensi Pegawai}

Setiap organisasi dibentuk untuk mencapai tujuan tertentu dan apabila tercapai, barulah dapat disebut sebagai sebuah keberhasilan. Untuk mencapai keberhasilan, diperlukan landasan yang kuat berupa : kompetensi kepemimpinan, kompetensi pegawai, dan budaya organisasi yang mampu memperkuat dan memaksimumkan kompetensi. Dalam penelitian ini yang menjadi pokok penelitian adalah kompetensi pegawai, dimana tujuan kebutuhan dalam penentuan tingkat atau level kompetensi seorang pegawai hanyalah untuk mengetahui tingkat kinerja pegawai tersebut apabila pegawai itu akan melakukan suatu pekerjaan, apakah hasilnya nanti termasuk dalam kategori level tinggi atau dibawah rata-rata. Kemampuan atau kompetensi seseorang termasuk dalam kategori tinggi atau baik nantinya akan dibuktikan dan ditunjukkan apabila seorang pegawai sudah melakukan pekerjaan (sudah bekerja). Sebaliknya, apabila mempunyai kompetensi tingkat rendah, seorang pegawai akan cenderung berkinerja rendah pula. Dengan demikian, kompetensi menjadi sangat berguna untuk menciptakan sumber daya manusia yang berkualitas dalam organisasi sehingga akan menciptakan budaya kinerja tinggi.

Menurut Spencer dan Spencer (dalam Moeheriono, 2010: 13), menyatakan dalam setiap individu seseorang terdapat beberapa elemen pembentuk kompetensi dasar, yang terdiri dari : karakterisitik pribadi/sifat, motif, konsep diri, pengetahuan dan keterampilan.

Penelitian ini terdapat 5 dimensi yang menjadi 19 indikator pernyataan untuk pengolahan data yang bertujuan untuk mengetahui jawaban pilihan responden yang ditabulasi pada lampiran. Untuk mengetahui penilaian responden terhadap variabel kompetensi pegawai, peneliti akan mendeskripsikan hasil penilaian responden melalui kuesioner penelitian terhadap variabel kompetensi pegawai. Adapun jawaban responden atas pernyataan terhadap dimensi-dimensi variabel kompetensi adalah sebagai berikut :

\section{Dimensi Karakterisitik Pribadi/sifat}

\section{Persentase Jawaban Responden Atas Pernyataan Dimensi Karakteristik Pribadi/Sifat}

$(\mathrm{n}=54)$

\begin{tabular}{|c|l|c|c|c|c|c|}
\hline \multirow{2}{*}{ No } & \multicolumn{5}{|c|}{ Pernyataan } & \multicolumn{5}{|c|}{ Jawaban } \\
\cline { 3 - 7 } & \multicolumn{1}{|c|}{ SS } & S & R & TS & STS \\
\hline 1 & $\begin{array}{l}\text { Pegawai mengendalikan emosi diri ketika } \\
\text { menghadapi tantangan atau penolakan dari } \\
\text { orang lain atau pada saat bekerja dibawah } \\
\text { tekanan. }\end{array}$ & 16,7 & 9,3 & 0 & 0 \\
\hline 2 & $\begin{array}{l}\text { Keyakinan seorang pegawai pada } \\
\text { kemampuan diri sendiri untuk } \\
\text { menyelesaikan suatu tugas atau tantangan. }\end{array}$ & 70,4 & 24,1 & 5,6 & 0 & 0 \\
\hline 3 & $\begin{array}{l}\text { Pegawai menyesuaikan diri dan bekerja } \\
\text { secara efektif pada berbagai situasi, dengan } \\
\text { berbagai rekan atau kelompok yang } \\
\text { berbeda. }\end{array}$ & & 24,1 & 13 & 0 & 0 \\
\hline 4 & $\begin{array}{l}\text { Pegawai menempatkan prioritas dan tujuan } \\
\text { organisasi atau misi dari organisasi di atas } \\
\text { keinginan diri sendiri. }\end{array}$ & 55,6 & 35,2 & 9,3 & 0 & 0 \\
\hline & Persentase Rata-rata & 65,7 & 25 & 9,3 & 0 & 0 \\
\hline
\end{tabular}

Sumber : Hasil Penelitian, 2014 
a. Pegawai mengendalikan emosi diri ketika menghadapi tantangan atau penolakan dari orang lain atau pada saat bekerja dibawah tekanan.

Berdasarkan analisa dari hasil penyebaran kuesioner pada penelitian ini dapat diperoleh jawaban responden sebesar 74,1\% menyatakan Sangat Setuju (SS) pada pernyataan ini, hal ini menunjukkan bahwa Pegawai Dinas Perhubungan Kabupaten Subang dapat mengendalikan emosi diri ketika menghadapi tantangan dari tugas yang diberikan atasan atau penolakan dari orang lain atau pada saat bekerja dibawah tekanan.

Dari pencapaian nilai di atas dapat disimpulkan bahwa nilai Self control (SCT) dari pegawai Dinas Perhubungan Kabupaten Subang yang merupakan kemampuan untuk mengendalikan emosi diri sudah baik, sehingga dalam mengerjakan tugas akan tenang dan terkendali dalam situasi apa pun dan juga akan dapat menumbuhkan kepercayaan diri yang tinggi dari pegawai itu.

b. Keyakinan seorang pegawai pada kemampuan diri sendiri untuk menyelesaikan suatu tugas atau tantangan.

Berdasarkan nilai kuesioner diatas, jawaban responden pada indikator ini mencapai sebesar $70,4 \%$ yang menyatakan Sangat Setuju (SS) hal ini menunjukkan bahwa pegawai Dinas Perhubungan Kabupaten Subang telah memiliki nilai Self confidence (SCF) yang merupakan keyakinan seseorang pada kemampuan diri sendiri untuk menyelesaikan suatu tugas atau tantangan

Faktor psikologis seorang pegawai akan sangat mempengaruhi dalam bersikap dan bertutur kata bahkan aka nada kecenderungan mempengaruhi kepribadian seorang pegawai, pribadi yang matang dan didukung oleh lingkungan keluarga akan meciptakan pribadi pegawai yang bagus pula yang memiliki nilai Self confidence (SCF) yang tinngi.

c. Pegawai menyesuaikan diri dan bekerja secara efektif pada berbagai situasi, dengan berbagai rekan atau kelompok yang berbeda.

Berdasarkan analisa dari hasil penyebaran kuesioner pada penelitian ini dapat diperoleh jawaban responden sebesar $63 \%$ yang menyatakan Sangat Setuju (SS) pada pernyataan ini, hal ini menunjukkan bahwa pegawai Dinas Perhubungan Kabupaten Subang telah memiliki kemampuan Flexibility (FLX) yang baik. Flexibility (FLX) merupakan kemampuan menyesuaikan diri dan bekerja secara efektif pada berbagai situasi, dengan berbagai rekan atau kelompok yang berbeda; kemampuan untuk memahami dan menghargai perbedaan dan pandangan yang bertentangan atas suatu isu. Nilai Flexibility (FLX) inilah yang harus dimiliki oleh seorang pegawai terutama pegawai yang baru memasuki lingkungan baru, kantor baru atau baru menduduki jabatan baru. Nilai Flexibility (FLX) dari setiap pegawai akan sangat berbeda satu sama lainya tergantung kemampuan pegawai untuk beradaptasi. Oleh karena itu setiap tugas atau pekerjaan akan cepat selesai apabila pegawai dapat membaca situasi dan karakter dari rekan kerjanya.

d. Pegawai menempatkan prioritas dan tujuan organisasi atau misi dari organisasi di atas keinginan diri sendiri.

Berdasarkan nilai kuesioner diatas, jawaban responden pada pernyataan ini hanya mencapai $55,6 \%$ yang menyatakan Sangat Setuju (SS) hal ini menunjukkan bahwa Organizational commitment (OC) belum maksimal diterapkan pada Dinas Perhubungan Kabupaten Subang. rendahnya nilai Organizational commitment (OC) umumnya terjadi karena kurangnya pengawasan dari pemerintah 
pusat, sehingga banyak pejabat daerah yang tersandung hukum kasus korupsi.

Organizational commitment (OC) yaitu merupakan kemampuan dan kemauan seseorang untuk mengaitkan apa yang diperbuat dengan kebutuhan, prioritas dan tujuan organisasi; berbuat sesuatu untuk mempromosikan tujuan organisasi atau untuk memenuhi kebutuhan organisasi; dan menempatkan misi organisasi diatas keinginan diri sendiri atau peran profesionalnya. Sejauh mana Organizational commitment (OC) tertanam dalam individu pegawai itu kunci pokok dari keberhasilan dalam mencapai tujuan orgnisasi. Masih banyaknya kepentingan setiap pegawai Dinas Perhubungan Kabupaten Subang sehingga nilai Organizational commitment (OC) tidak signifikan.

\section{Dimensi Motif}

\section{Persentase Jawaban Responden Atas Pernyataan Dimensi Motif}

\begin{tabular}{|c|l|c|c|c|c|c|}
\hline \multicolumn{1}{|c|}{$(\mathbf{n}=\mathbf{5 4})$} \\
\cline { 3 - 7 } No & \multicolumn{1}{|c|}{ Jernyataan } & SS & S & R & TS & STS \\
\hline 5 & $\begin{array}{l}\text { Pegawai berusaha untuk meraih kekuasan } \\
\text { atau posisi dalam organisasi. }\end{array}$ & 25,9 & 53,7 & 13 & 7,4 & 0 \\
\hline 6 & $\begin{array}{l}\text { Pegawai menjalin dan membina hubungan } \\
\text { sosial atau jaringan hubungan sosial agar } \\
\text { tetap hangat dan akrab dengan atasan dan } \\
\text { pegawai lain. }\end{array}$ & 50 & 37 & 9,3 & 3,7 & 0 \\
\hline 7 & $\begin{array}{l}\text { Pegawai perduli terhadap pekerjaannya, } \\
\text { sehingga terdorong berusaha untuk } \\
\text { bekerja lebih baik. }\end{array}$ & 74,1 & 25,9 & 0 & 0 & 0 \\
\hline Persentase Rata-rata & 50 & 38,9 & 7,4 & 3,7 & 0 \\
\hline
\end{tabular}

Sumber : Hasil Penelitian, 2014
a. Pegawai berusaha untuk meraih kekuasan atau posisi dalam organisasi.

Berdasarkan hasil analisa kuesioner jawaban dari 54 responden sebagaian besar menjawab Sangat Setuju (SS) sebesar $25,9 \%$ dan yang menjawab Setuju (S) adalah sebesar $53,7 \%$ perbedaan ini terjadi karena ada keragu-raguan dari responden pada jawaban indikator peryataan ini sehingga jawaban setuju lebih tinggi dari jawaban sangat setuju karena motif dari setiap pegawai yang berbeda dan umumnya tertutup. Namun secara garis besarnya, hal ini menunjukkan bahwa sebagian besar pegawai Dinas Perhubungan Kabupaten Subang selalu berusaha untuk meraih kekuasan atau posisi jabatan. Perbedaan pemahaman pegawai Dinas Perhubungan Kabupaten Subang tentang Organizational awareness (OA) mengakibatkan jawaban responden yang relatif berbeda - beda.

Berdasarkan analisa penulis hal itu terjadi karena adanya perbedaan motif dari pegawai itu sendiri yang berbeda dalam setiap melakasanakan tugas yang diberikan. Motif dari pegawai yang berusaha untuk mengejar kekuasaan atau jabatan tidak selamanya negatif selama masih dalam koridor yang benar dan tidak melanggar hokum dan beretika. Pegawai yang berambisi umumnya selalu menghasilkan kinerja tinggi.

b. Pegawai menjalin dan membina hubungan sosial atau jaringan hubungan sosial agar tetap hangat dan akrab dengan atasan dan pegawai lain. 
Dari hasil analisa tabel di atas, dapat dilihat bahwa Dinas Perhubungan Kabupaten Subang menjalin dan membina hubungan sosial atau jaringan hubungan sosial agar tetap hangat dan akrab dengan atasan dan pegawai lain, yang dibuktikan dengan jawaban terbesar dari kuesioner adalah pernyataan Sangat Setuju (SS) sebesar 50\%, sehingga pada dasarnya jawaban dari indikator ini menunjukkan bahwa hubungan harmonis tercipta antara setiap pegawai satu sama lainnya dan antara pegawai dengan atasan.

Proses Relationship building (RB) yang merupakan besarnya usaha untuk menjalin dan membina hubungan sosial atau jaringan hubungan sosial agar tetap hangat dan akrab pada Dinas Perhubungan Kabupaten Subang akan sangat mempengaruhi kompetensi pegawai, situasi sosial dalam kantor yang kondusif akan berpengaruh pada kinerja yang dihasilkan pula. Meningkatkan Relationship building dan menghindari konflik antar pegawai merupakan gambaran dari kompetensi pegawai yang tinggi.

\section{Dimensi Konsep Diri}

\section{Persentase Jawaban Responden Atas Pernyataan Dimensi Konsep Diri}

$(\mathrm{n}=54)$

\begin{tabular}{|c|l|c|c|c|c|c|}
\hline \multirow{2}{*}{ No } & \multicolumn{1}{|c|}{ Pernyataan } & \multicolumn{5}{|c|}{ Jawaban } \\
\cline { 3 - 7 } & \multicolumn{1}{|c|}{ SS } & S & R & TS & STS \\
\hline 8 & $\begin{array}{l}\text { Mengirim seorang pegawai ke program } \\
\text { training secara rutin untuk memenuhi } \\
\text { kebutuhan pekerjaan dan organisasi. }\end{array}$ & 74,1 & 25,9 & 0 & 0 & 0 \\
\hline 9 & $\begin{array}{l}\text { Mendapatkan teguran karena melanggar } \\
\text { aturan adalah hal wajar yang harus } \\
\text { diterima. }\end{array}$ & 66,7 & 27,8 & 3,7 & 1,9 & 0 \\
\hline 10 & $\begin{array}{l}\text { Bekerja dengan orang lain dalam satu } \\
\text { tim adalah lebih baik daripada bekerja } \\
\text { secara sendirian. }\end{array}$ & 72,2 & 24 & 1,9 & 1,9 & 0 \\
\hline 11 & $\begin{array}{l}\text { Semua pegawai berkeinginan untuk } \\
\text { berperan sebagai pemimpin tim atau } \\
\text { kelompok lain. Jadi berkaitan dengan } \\
\text { keinginan untuk memimpin orang lain. }\end{array}$ & 40,7 & 46,3 & 11,1 & 1,9 & 0 \\
\hline
\end{tabular}




\begin{tabular}{|c|c|c|c|c|c|c|}
\hline 12 & $\begin{array}{l}\text { Pegawai harus menggunakan sebagian } \\
\text { waktunya untuk memikirkan tentang apa } \\
\text { yang orang lain pikir dan rasakan. }\end{array}$ & 22,2 & 70,3 & 5,6 & 1,9 & 0 \\
\hline Persentase Rata-rata & 55,2 & 38,8 & 4,5 & 1,5 & 0 \\
\hline
\end{tabular}

Sumber : Hasil Penelitian, 2014

a. Mengirim seorang pegawai ke program training secara rutin untuk memenuhi kebutuhan pekerjaan dan organisasi.

Berdasarkan nilai kuesioner diatas, diperoleh jawaban responden pada pernyataan ini yaitu sebesar $74,1 \%$ yang menyatakan Sangat Setuju (SS) dan yang menyatakan Setuju (S) mencapai 25,9\%, yang menyatakan Ragu atau Tidak Setuju sama sekali tidak ada. Hal ini menunjukkan bahwa pada umumnya pegawai Dinas Perhubungan Kabupaten Subang sangat setuju dengan mengirim pegawai ke program training secara rutin untuk memenuhi kebutuhan pekerjaan dan organisasi, akan meningkatkan kompetensi pegawai itu sendiri pada saat bekerja nanti, memecahkan masalah atau untuk persiapan pada saat akan menduduki suatu jabatan baru pada Dinas Perhubungan Kabupaten Subang.

Sumber daya manusia yang kompeten dan berkualitas sangat dibutuhkan untuk mendukung produktivitas dan aktivitas agar tujuan suatu organisasi dapat tercapai dengan sempurna. Sumber daya manusia mempunyai peran utama dalam kegiatan organisasi. Walaupun di dukung dengan sarana dan prasarana serta sumber dana yang berlebihan, tetapi tanpa dukungan sumber daya manusia yang handal kegiatan organisasi tidak akan terselesaikan dengan baik.

b. Mendapatkan teguran karena melanggar aturan adalah hal wajar yang harus diterima.

Berdasarkan nilai kuesioner diatas, diperoleh jawaban responden pada pernyataan ini yaitu sebesar $66,7 \%$ yang menyatakan Sangat Setuju (SS). Hal ini menunjukkan bahwa pada umumnya pegawai Dinas Perhubungan Kabupaten Subang bersedia mendapatkan teguran karena melanggar aturan adalah hal wajar yang harus diterima. Adapun responden yang menjawab Tidak Setuju (TS) sebesar $1,9 \%$ hanya sebagian kecil dari pegawai Dinas Perhubungan Kabupaten Subang yang merupakan pegawai bersifat status quo akibat dari pola pikir yang masih berasaskan turun temurun.

Salah satu hal yang mempengaruhi kinerja pegawai adalah disiplin. Karena tanpa adanya disiplin, maka segala kegiatan yang dilakukan akan mendatangkan hasil yang kurang memuaskan, tidak sesuai harapan. Hal ini dapat mengakibatkan kurangnya pencapaian sasaran dan tujuan organisasi serta dapat menghambat program organisasi yang dibuat. Disiplin merupakan sebuah titik awal dari segala kesuksesan dalam rangka mencapai tujuan sebuah organisasi. Penerapan disiplin dalam suatu organisasi bertujuan agar semua pegawai dalam orgnisasi bersedia bersukarela mematuhi serta mentaati setiap tata tertib yang berlaku tanpa ada unsur paksaan.

c. Bekerja dengan orang lain dalam satu tim adalah lebih baik daripada bekerja secara sendirian.

Pada Dinas Perhubungan Kabupaten Subang pegawainya sudah sadar dan tahu arti pentingnya bekerja dalam satu tim dari pada bekerja sendiri, prinsip Teamwork and cooperation (TW), yang berarti kemauan sungguh-sungguh untuk bekerja secara kooperatif dengan pihak lain, menjadi bagian sebuah tim, bekerja bersama sehingga menjadi lebih kompetitif diterapkan pada pegawai Dinas Perhubungan Kabupaten Subang. Hal ini dapat dilihat dari jawaban responden yang mencapai sebesar $72,2 \%$ yang menjawab 
Sangat Setuju untuk pernyataan bekerja dengan orang lain dalam satu tim adalah lebih baik daripada bekerja secara sendirian. Adapun sisanya adalah termasuk pegawai yang tidak bisa bekerja dalam satu tim yang diakibatkan oleh faktor ego, ketidaktentraman atau juga karena kenaipan dari pegawai itu.

Dalam bekerja kita tidak seorang diri, tetapi bekerja dengan orang lain dalam satu tim. Oleh karena itu, perlu mempelajari prinsip-prinsip bekerjasama dalam satu tim. Bekerja dalam bentuk tim akan lebih efektif dari pada bekerja sendiri-sendiri. Bekerja dalam satu tim memiliki banyak fungsi dan manfaat. Fungsi bekerja dalam tim antara lain dapat mengubah sikap, perilaku, dan nilai-nilai pribadi, serta dapat turut serta dalam mendisiplinkan anggota lainnya. Selain itu tim dapat digunakan untuk pengambilan keputusan, merundingkan, dan bernegosiasi. Anggota tim dengan latar belakang yang berbeda-beda mungkin saja membawa persepektif atau pengaruh positif terhadap proses pengambilan keputusan.

d. Semua pegawai berkeinginan untuk berperan sebagai pemimpin tim atau kelompok lain. Jadi berkaitan dengan keinginan untuk memimpin orang lain.

Dari hasil analisa tabel di atas dapat dilihat bahwa jawaban responden tertinggi yaitu sebesar 46,3\% yang menyatakan Setuju (S), pada pernyataan Semua pegawai berkeinginan untuk berperan sebagai pemimpin tim atau kelompok lain. Jadi berkaitan dengan keinginan untuk memimpin orang lain. Hal ini menunjukkan bahwa pegawai Dinas Perhubungan Kabupaten Subang tidak semua pegawai berkeinginan untuk menjadi seorang Team leadership pada sebuah kelompok kerja atau pada kelompok kerja bersama instansi yang lain juga.

Sebuah organisasi akan selalu membutuhkan pemimpin tim/Team leadership (TL) yaitu kemauan untuk berperan sebagai pemimpin tim atau kelompok lain. Jadi berkaitan dengan keinginan untuk memimpin orang lain. Team Leadership lazimnya terlihat dalam posisi otoritas formal. Pemimpin yang dimaksud disini adalah pemimpin yang mampu bekerja mengelola tim, di mana ide-idenya bisa diterapkan dalam memecahkan masalah atau dalam menjalankan program dan juga memiliki jiwa visioner. Namun kenyataannya, tidak semua orang memiliki kemampuan untuk memimpin atau bisa menjadi seorang Team leadership.

e. Pegawai harus menggunakan sebagian waktunya untuk memikirkan tentang apa yang orang lain pikir dan rasakan.

Dari hasil analisa tabel di atas dapat dilihat bahwa jawaban responden cukup signifikan yaitu sebesar $70,3 \%$ yang menyatakan Setuju (S), pada pernyataan Pegawai harus menggunakan sebagian waktunya untuk memikirkan tentang apa yang orang lain pikir dan rasakan. Hal ini menunjukkan bahwa pada umumnya pegawai Dinas Perhubungan Kabupaten Subang harus menggunakan sebagian waktunya untuk memikirkan tentang apa yang orang lain pikir dan rasakan.

Hal itu dilakukan semata-mata untuk meningkatkan kompetensi pegawai dalam Interpersonal understanding (IU) yang merupakan kemampuan untuk memahami dan mendengarkan hal-hal yang tidak diungkapkan dengan perkataan, bisa berupa pemahaman atas perasaan, keinginan atau pemikiran orang lain. Untuk menumbuhkan Interpersonal understanding yaitu dengan dengan menciptakan hubungan interpersonal terlebih dahulu. Jadi ketika kita berkomunikasi kita tidak hanya menentukan content melainkan juga menentukan relationship. Salah satu dasar untuk membangun hubungan interpersonal adalah ketertarikan dengan orang lain. Ketertarikan yang dimaksud disini adalah perasaan positif kepada orang lain. Adapun yang menjadi komponen kunci dari Interpersonal understanding ini adalah 
mendengarkan secara efektif dan memiliki

empathy atas perasaan orang lain.

\section{Dimensi Pengetahuan}

\section{Persentase Jawaban Responden Atas Pernyataan Dimensi Pengetahuan}

\begin{tabular}{|c|l|c|c|c|c|c|}
\hline \multicolumn{1}{|c|}{ (n = 54 ) } & \multicolumn{5}{c|}{ Jawaban } \\
\cline { 3 - 7 } No & \multicolumn{1}{|c|}{ SS } & S & R & TS & STS \\
\hline 13 & $\begin{array}{l}\text { Langkah-langkah sistematis yang logis } \\
\text { dalam menyelesaikan suatu masalah adalah } \\
\text { metode yang terbaik untuk memecahkan } \\
\text { masalah. }\end{array}$ & 77,8 & 18,5 & 3,7 & 0 & 0 \\
\hline 14 & $\begin{array}{l}\text { Selalu bekerja dengan arah yang pasti, } \\
\text { ketika dalam menyelesaikan suatu masalah } \\
\text { telah ada prosedur yang jelas yang harus } \\
\text { diikuti. }\end{array}$ & & 18,5 & 0 & 0 & 0 \\
\hline 15 & $\begin{array}{l}\text { Pegawai mengetahui pekerjaan yang } \\
\text { dilakukan secara jelas dan paham. }\end{array}$ & 70,4 & 24,1 & 5,5 & 0 & 0 \\
\hline \multicolumn{1}{|c|}{ Persentase Rata-rata } & 76,6 & 20,4 & 3 & 0 & 0 \\
\hline
\end{tabular}

a. Langkah-langkah sistematis yang logis dalam menyelesaikan suatu masalah adalah metode yang terbaik untuk memecahkan masalah.

Berdasarkan hasil analisa kuesioner diatas dapat diperoleh jawaban dari responden pada pernyataan Langkahlangkah sistematis yang logis dalam menyelesaikan suatu masalah adalah metode yang terbaik untuk memecahkan masalah, sebanyak $77,8 \%$ responden yang menyatakan Sangat Setuju (SS) dan tidak ada satu pun yang menyatakan Tidak Setuju/Sangat Tidak Setuju. Hal ini menunjukkan bahwa setiap dalam penyelesaian suatu masalah pada umumnya pegawai Dinas Perhubungan Kabupaten Subang menggunakan metode Analytical thinking (AT), yaitu kemampuan memahami situasi dengan merincinya menjadi bagian-bagian kecil, atau melihat implikasi sebuah situasi secara rinci.

b. Selalu bekerja dengan arah yang pasti, ketika dalam menyelesaikan suatu masalah telah ada prosedur yang jelas yang harus diikuti.
Dari hasil analisa tabel di atas dapat dilihat bahwa jawaban responden sangat siginifikan yang menyatakan Sangat Setuju (SS) yaitu sebesar $81,5 \%$ dan tidak ada jawaban yang menyatakan Ragu , Tidak setuju dan Sangat Tidak Setuju, pada pernyataan selalu bekerja dengan arah yang pasti, ketika dalam menyelesaikan suatu masalah telah ada prosedur yang jelas yang harus diikuti. Artinya pegawai Dinas Pehubungan Kabupaten Subang dalam menyelesaikan masalah menggunakan metode Conceptual thinking (CT) yaitu memahami sebuah situasi atau masalah dengan menempatkan setiap bagian menjadi satu kesatuan untuk mendapatkan gambar yang lebih besar. Termasuk kemampuan mengidentifikasi pola atau hubungan antar situasi yang tidak secara jelas terkait; mengidentifikasi isu mendasar atau kunci dalam situasi yang kompleks. CT bersifat kreatif, konsepsional, atau induktif.

c. Pegawai mengetahui pekerjaan yang dilakukan secara jelas dan paham.

Berdasarkan jawaban responden pada pernyataan ini, sebesar $70,4 \%$ 
menyatakan Sangat Setuju (SS) dan tidak ada satu pun respoden yang menyatakan Tidak Setuju (TS) atau jawaban Sangat Tidak Setuju (STS), artinya pegawai Dinas Perhubungan Kabupaten Subang mengetahui pekerjaan yang dilakukan secara jelas dan paham.

Hal ini sesuai dengan pengamatan penulis, pegawai Dinas Perhubungan Kabupaten Subang mengetahui, menyadari Dimensi Keterampilan apa yang harus dilakukan dan mempunyai perhatian terhadap pekerjaannya, mampu mengarahkan diri sendiri dan mampu meningkatkan kemampuan terhadap tugas pekerjaan yang diberikan kepada pegawai itu. Karena spesifikasi tugas, pekerjaan atau jabatan yang diduduki pegawai sesuai dengan lulusan akademisi yang di sandangnya.

\section{Persentase Jawaban Responden Atas Pernyataan Dimensi Keterampilan}

\begin{tabular}{|c|c|c|c|c|c|c|}
\hline \multirow{3}{*}{ No } & \multirow{3}{*}{ Pernyataan } & & & & & \\
\hline & & \multicolumn{5}{|c|}{ Jawaban } \\
\hline & & SS & $\mathrm{S}$ & $\mathrm{R}$ & $\mathrm{TS}$ & STS \\
\hline 16 & $\begin{array}{l}\text { Bertanya tanpa mengharapkan jawaban, } \\
\text { akan sangat membuang-buang waktu. }\end{array}$ & 75,9 & 24,1 & 0 & 0 & 0 \\
\hline 17 & $\begin{array}{l}\text { Kadang-kadang/dalam kondisi-kondisi } \\
\text { tertentu, antusiasme sangat diperlukan. }\end{array}$ & 13 & 59,2 & 20,4 & 7,4 & 0 \\
\hline 18 & $\begin{array}{l}\text { Pegawai melakukan tindakan } \\
\text { membujuk, meyakinkan, mempengaruhi } \\
\text { atau mengesankan sehingga orang lain } \\
\text { mau mendukung agendanya. }\end{array}$ & 46,3 & 44,4 & 9,3 & 0 & 0 \\
\hline 19 & $\begin{array}{l}\text { Pegawai selalu berusaha untuk } \\
\text { mengumpulkan informasi lebih banyak } \\
\text { tentang tugas yang diberikan. }\end{array}$ & 53,7 & 40,7 & 3,7 & 1,9 & 0 \\
\hline & Persentase Rata-rata & 47,2 & 42,1 & 8,4 & 2,3 & 0 \\
\hline
\end{tabular}

Sumber : Hasil Penelitian, 2014

a. Bertanya tanpa mengharapkan jawaban, akan sangat membuangbuang waktu.

Berdasarkan hasil analisa kuesioner diatas dapat diperoleh jawaban dari responden pada pernyataan Bertanya tanpa mengharapkan jawaban, akan sangat membuang-buang waktu, mayoritas responden menjawab Sangat Setuju (SS) yaitu sebesar $75,9 \%$ dan tidak ada responden yang menjawab Ragu, Tidak atau Sangat Tidak Setuju.

Hal ini menunjukkan bahwa mayoritas responden menyatakan bertanya tanpa mengharapkan jawaban, akan sangat membuang-buang waktu. nilai jawaban responden diatas juga mengisyarakatkan bahwa pegawai pada Dinas Perhubungan Kabupaten mengetahui arti pentingnya kompetensi Concern for order yang harus dimiliki oleh setiap pegawai,baik pada pegawai lama maupun pegawai baru. Concern for order (CO), merupakan dorongan dalam diri seseorang untuk mengurangi ketidakpastian di lingkungan sekitarnya, khususnya berkaitan dengan pengaturan kerja, instruksi, informasi dan data.

b. Kadang-kadang/dalam kondisikondisi tertentu, antusiasme sangat diperlukan.

Berdasarkan hasil analisa kuesioner tabel diatas pada pernyataan kadangkadang/dalam kondisi-kondisi tertentu, antusiasme sangat diperlukan, menunjukkan bahwa responden pegawai Dinas Perhubungan Kabupaten Subang 
sebanyak 59,2\% yang menyatakan Setuju (S), hal ini menunjukkan bahwa pegawai Dinas Perhubungan Kabupaten Subang sikap Initiative ini hanya sebagian saja yang memilikinya, pegawai yang tidak memliki sikap Initiative dikarenakan tidak mau terbentur masalah administrasi, takut mendapat teguran dari atasan atau selalu mengikuti prosedur yang telah ada.

Kondisi tertentu dimana pada saat pegawai dipaksa untuk mengambil keputusan atau dihadapkan pada permasalahan maupun pekerjaan yang sudah harus deadline namun pimpinan sedang tidak berada di kantor, di situ dibutuhkan Initiative (INT) yang merupakan dorongan bertindak untuk melebihi yang dibutuhkan atau yang dituntut dari pekerjaan, melakukan sesuatu tanpa menunggu perintah lebih dahulu.

\section{c. Pegawai melakukan tindakan membujuk, meyakinkan, mempengaruhi atau mengesankan sehingga orang lain mau mendukung agendanya.}

Berdasarkan hasil analisa kuesioner diatas pada pernyataan pegawai melakukan tindakan membujuk, meyakinkan, mempengaruhi atau mengesankan sehingga orang lain mau mendukung agendanya, jawaban responden yang menyatakan Sangat Setuju (SS) yaitu sebesar 46,3\% dan 44,4\% yang menyatakan Setuju (S), yang menyatakan Tidak Setuju (TS) dan Sangat Tidak Setuju (STS) sama sekali tidak ada jawaban.

Keinginan dari pegawai Dinas Perhubungan Kabupaten Subang untuk melakukan tindakan membujuk, meyakinkan, mempengaruhi atau mengesankan sehingga orang lain mau mendukung agendanya atau yang disebut juga dengan Impact and influence (IMP) merupakan kompetensi yang penting dan wajib dimiliki oleh seluruh pegawai tanpa memandang jabatan.

d. Pegawai selalu berusaha untuk mengumpulkan informasi lebih banyak tentang tugas yang diberikan.

Berdasarkan hasil analisa kuesioner diatas pada pernyataan Pegawai selalu berusaha untuk mengumpulkan informasi lebih banyak tentang tugas yang diberikan, responden yang menjawab Sangat Setuju (SS) yaitu sebesar 53,7\%. Hal ini menunjukkan pegawai Dinas Perhubungan Kabupaten Subang telah mengetahui arti penting dari kompetensi mengumpulkan data dan informasi atau disebut juga dengan information seeking (INFO).

Setiap organisasi selalu melakukan tindakan-tindakan penting guna mencapai tujuan melalui pemanfaatan data atau informasi yang ada. Data atau informasi begitu penting untuk pelaksanaan tindakan yang diawali dari pengambilan keputusan yang tepat. Tanpa data atau informasi, mustahil keputusan dapat diambil. Bila dipaksakan, maka tindakan yang diambil berdasarkan keputusan tersebut akan berakibat fatal.

\section{Analisa Skor Keseluruhan Variabel Kompetensi}

Berdasarkan data kuesioner yang telah diolah, maka di bawah ini disajikan persentase keseluruhan jawaban responden atas pernyataan-pernyataan yang diajukan dalam kompetensi pegawai Dinas Perhubungan Kabupaten Subang, perhitungan tiap pernyataan secara menyeluruh dapat dilihat pada chart sebagai berikut : 


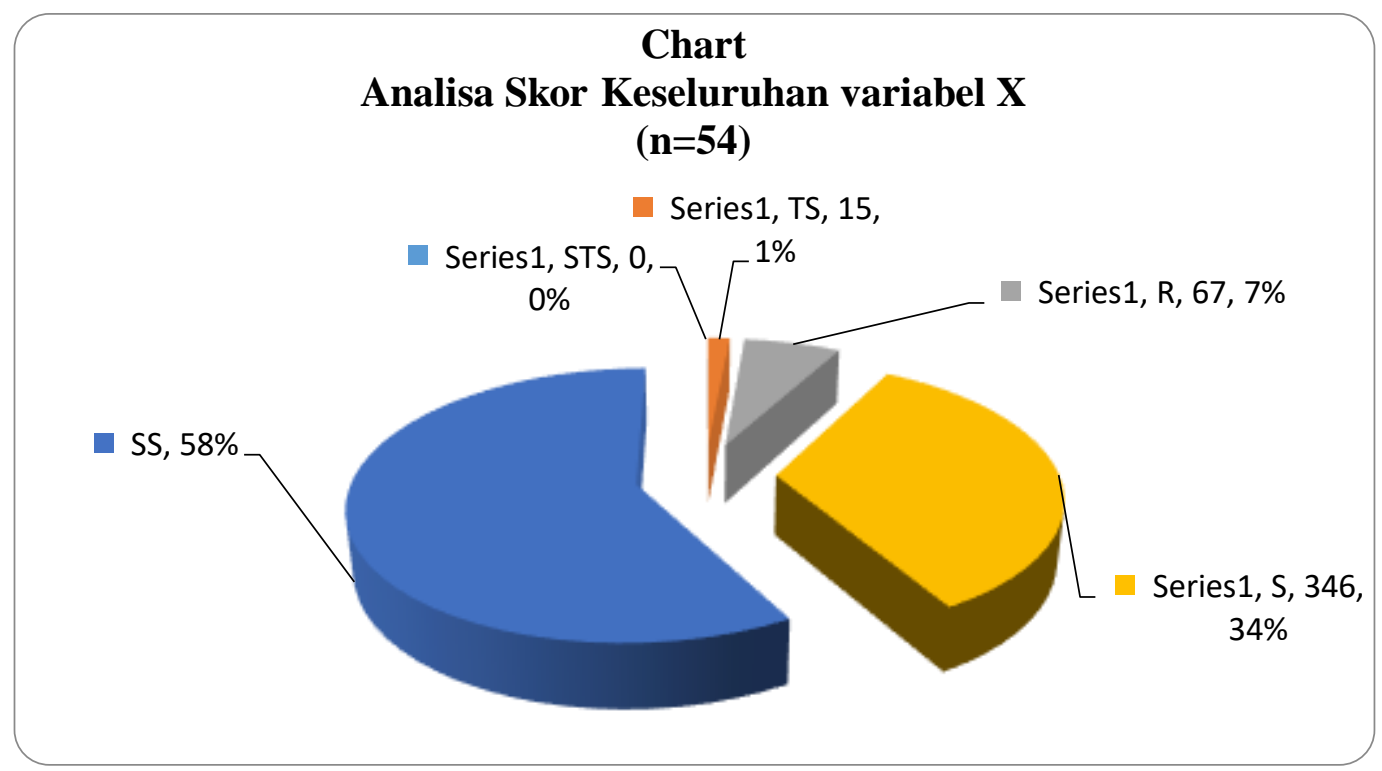

Pada chart diatas, maka dapat dilihat bahwa secara umum, frekuensi terbesar jawaban responden untuk tiap pernyataan dalam variabel kompetensi tersebut yang paling dominan responden memberikan jawaban sangat setuju (ss). Dari besarnya persentase ini, dapat disimpulkan bahwa upaya kompetensi pada Dinas Perhubungan Kabupaten Subang telah dilaksanakan sesuai dengan komponen-komponen kompetensi yaitu karakteristik pribadi/sifat, motif, konsep diri, pengetahuan dan keterampilan.

\section{Deskripsi Variabel Kinerja Pegawai}

Kinerja atau performance merupakan gambaran mengenai tingkat pencapaian pelaksanaan suatu program kegiatan atau kebijakan dalam mewujudkan sasaran, tujuan, visi dan misi organisasi yang dituangkan melalui perencanaan strategis suatu organisasi. Kinerja dapat diketahui dan diukur jika individu atau sekelompok pegawai telah mempunyai kriteria atau standar keberhasilan tolak ukur yang ditetapkan oleh organisisi. Oleh karena itu tanpa tujuan dan target yang ditetapkan dalam pengukuran, maka maka kinerja pada seseorang atau kinerja pada organisasi tidak mungkin dapat diketahui bila tidak ada tolak ukur keberhasilannya. Menurut Yoder dalam Sastrohadiwiryo (2005: 236) mengemukakan beberapa sifat yang paling umum diadakan penilaian dari para pegawai yang bekerja dengan tangan atau pegawai di bidang produksi, pegawai administratif, dan pegawai yang memiliki kedudukan sebagai manajemen dalam suatu organisasi yaitu : kualitas kerja, kuantitatif, kerjasama, inisiatif dan tanggung jawab.

Penelitian ini terdapat 5 dimensi yang menjadi 20 indikator pernyataan untuk pengolahan data yang bertujuan untuk mengetahui jawaban pilihan responden yang ditabulasi pada lampiran. Untuk mengetahui penilaian responden terhadap variabel kinerja pegawai, peneliti akan mendeskripsikan hasil penilaian responden melalui kuesioner penelitian terhadap variabel kinerja pegawai. Adapun jawaban responden atas pernyataan terhadap dimensi-dimensi variabel kinerja adalah sebagai berikut : 


\section{Dimensi Kualitas Kerja}

\section{Persentase Jawaban Responden Atas Pernyataan Dimensi Kualitas Kerja}

\begin{tabular}{|c|l|c|c|c|c|c|}
\hline \multirow{2}{*}{ No } & \multicolumn{1}{|c|}{ Jernyataan } & \multicolumn{5}{c|}{ Jawaban } \\
\cline { 3 - 7 } & \multicolumn{1}{|c|}{ SS } & S & R & TS & STS \\
\hline 1 & $\begin{array}{l}\text { Pegawai telah menunjukkan perhatian } \\
\text { pada aspek detail, akurasi, kecermatan } \\
\text { dan ketelitian dalam bekerja. }\end{array}$ & 53,7 & 46,3 & 0 & 0 & 0 \\
\hline 2 & $\begin{array}{l}\text { Pegawai senantiasa mematuhi peraturan } \\
\text { dan prosedur kesehatan dan keselamatan } \\
\text { kerja sesuai dengan bidang tugas dan } \\
\text { tanggung jawabnya. }\end{array}$ & 59,3 & 29,6 & 11,1 & 0 & 0 \\
\hline 3 & $\begin{array}{l}\text { Pegawai mampu membuat keputusan } \\
\text { yang berhubungan dengan pekerjaan dan } \\
\text { mengembangkan solusi alternatif. }\end{array}$ & 48,1 & 33,3 & 9,3 & 0 & 9,3 \\
\hline 4 & $\begin{array}{l}\text { Pegawai telah memahami segala } \\
\text { konsekuensi keputusan dan tindakan } \\
\text { yang diambilnya sesuai dengan tugas } \\
\text { dan tanggung jawabnya. }\end{array}$ & 53,7 & 27,7 & 9,3 & 9,3 & 0 \\
\hline \multicolumn{1}{|l|}{ Persentase Rata-rata } & 53,7 & 34,2 & 7,4 & 2,3 & 2,3 \\
\hline
\end{tabular}

Sumber : Hasil Pengujian, 2014

a. Pegawai telah menunjukkan perhatian pada aspek detail, akurasi, kecermatan dan ketelitian dalam bekerja.

Berdasarkan hasil analisa kuesioner diatas pada pernyataan pegawai telah menunjukkan perhatian pada aspek detail, akurasi, kecermatan dan ketelitian dalam bekerja, sebanyak $53,7 \%$ responden menyatakan Sangat Setuju (SS) dan sisanya sebanyak 46,3\% menyatakan Setuju (S).

Hal ini menunjukkan penguasaan teknologi dan pengetahuan dalam bidangnya masing-masing membuat setiap tugas dan pekerjaan yang dikerjakan oleh pegawai Dinas Perhubungan Kabupaten Subang dapat terselesaikan dengan baik dan tepat sasaran, ini dikarenakan oleh pegawai Dinas Perhubunga Kabupaten Subang selalu mengerjakannya dengan mengikuti SOP yang ada dan sesuai TUPOKSI masing-masing pegawai sehingga tidak terjadi tumpang tindih tugas. Suasana kondusif pada organisasi yang medukung secara sosial budaya juga memberikan pengaruh posisif pada pegawai dalam perhatian pada aspek detail, akurasi, kecermatan dan ketelitian dalam bekerja sehingga kinerja yang dihasilkan pun akan baik.

b. Pegawai senantiasa mematuhi peraturan dan prosedur kesehatan dan keselamatan kerja sesuai dengan bidang tugas dan tanggung jawabnya. Berdasarkan analisa hasil jawaban responden pada tabel diatas pada pernyataan pegawai senantiasa mematuhi peraturan dan prosedur kesehatan dan keselamatan kerja sesuai dengan bidang tugas dan tanggung jawabnya, responden sebanyak 59,3\% menyatakan Sangat Setuju (SS).

Hal ini menunjukkan bahwa pegawai Dinas Perhubungan Kabupaten Subang dalam pelayanan publik yaitu pelayanan uji KIR dapat cepat tanpa ada proses yang berbelit-belit dan juga dapat 
melindungi masyarakat dan pegawai dinas perhubungan itu sendiri dari kecelakaan kerja. Dalam hal ini juga dibutuhkan kerjasama antara pegawai dan masyarakat selaku pengguna layanan publik untuk mengikuti prosedur kesehatan dan keselamatan kerja supaya sasaran kinerja dari pegawai Dinas Perhubungan Kabupaten Subang akan tercapai.

c. Pegawai mampu membuat keputusan yang berhubungan dengan pekerjaan dan mengembangkan solusi alternatif.

Berdasarkan analisa hasil jawaban responden pada tabel diatas pernyataan pegawai mampu membuat keputusan yang berhubungan dengan pekerjaan dan mengembangkan solusi alternatif, responden memberikan jawaban yang beragam, sehingga jawaban responden tidak begitu signifikan pada pernyataan ini, jawaban responden tertinggi hanya sebesar $48,1 \%$ yang menyatakan Sangat Setuju, artinya tidak semua pegawai Dinas Perhubungan Kabupaten Subang dapat membuat keputusan yang berhubungan dengan pekerjaan dan mampu mengembangkan solusi alternatif maka segala keputusan yang berhubungan dengan pekerjaan dibutuhkan kordinasi yang antara atasan dan bawahan sehingga keputusan yang diambil akan tepat sasaran sesuai dengan yang diharapkan. Hal ini berarti kinerja pegawai Dinas Perhubungan Kabupaten Subang harus mengembangkan indikator ini supaya keputusan yang dihasilkan akan tepat dan bisa mengembangkan solusi alternative dalam menyelesaikan permsalahan.

d. Pegawai telah memahami segala konsekuensi keputusan dan tindakan yang diambilnya sesuai dengan tugas dan tanggung jawabnya.

Dari hasil analisa tabel di atas dapat dilihat bahwa sebesar $53,7 \%$ responden menyatakan Sangat Setuju (SS), hal ini menunjukkan bahwa pegawai Dinas Perhubungan Kabupaten Subang telah memahami segala konsekuensi keputusan dan tindakan yang diambilnya sesuai dengan tugas dan tanggung jawabnya, hasil ini didukung oleh dari hasil analisa penelitian penulis bahwa pegawai Dinas Perhubungan Kabupaten Subang tahu dan paham betul dengan sanksi administratif berlaku di kantor sesuai dengan PP Nomor 53 Tahun 2010 tentang disiplin PNS. Aturan tersebut menjadi rambu-rambu bagi pegawai dalam membuat keputusan dan bertindak karena kinerja baik seorang pegawai sudah pasti tidak akan melanggar aturan yang berlaku.

\section{Dimensi Kuantitas Kerja}

\section{Persentase Jawaban Responden Atas Pernyataan Dimensi Kuantitas Kerja}

\begin{tabular}{|c|c|c|c|c|c|c|}
\hline \multirow{3}{*}{ No } & $(\mathbf{n}=$ & & & & & \\
\hline & \multirow{2}{*}{ Pernyataan } & \multicolumn{5}{|c|}{ Jawaban } \\
\hline & & SS & $\mathrm{S}$ & $\mathrm{R}$ & TS & STS \\
\hline 5 & $\begin{array}{l}\text { Pegawai mampu menyelesaikan tugas } \\
\text { kerja yang diberikan secara konsisten. }\end{array}$ & 51,9 & 29,6 & 18,5 & 0 & 0 \\
\hline 6 & $\begin{array}{l}\text { Pegawai mampu menentukan dan } \\
\text { mengatur prioritas kerja secara efektif. }\end{array}$ & 57,4 & 31,5 & 11,1 & 0 & 0 \\
\hline 7 & $\begin{array}{l}\text { Pegawai mampu menggunakan waktu } \\
\text { dengan efisien dalam melaksanakan } \\
\text { segala tugas yang dibebankan } \\
\text { kepadanya. }\end{array}$ & 53,7 & 27,8 & 1,8 & 9,3 & 7,4 \\
\hline 8 & $\begin{array}{l}\text { Pegawai dapat memelihara tempat kerja } \\
\text { tetap teratur sesuai dengan fungsinya. }\end{array}$ & 57,4 & 31,5 & 11,1 & 0 & 0 \\
\hline
\end{tabular}




\begin{tabular}{|c|c|c|c|c|c|}
\hline Persentase Rata-rata & 55,1 & 30,1 & 10,6 & 2,3 & 1,9 \\
\hline & & & & & \\
\hline
\end{tabular}

a. Pegawai mampu menyelesaikan tugas kerja yang diberikan secara konsisten.

Berdasarkan analisa hasil jawaban responden yang pada tabel diatas, menyatakan bahwa pegawai Dinas Perhubungan Kabupaten Subang mampu menyelesaikan tugas kerja yang diberikan secara konsisten mencapai sebesar 51,9\% menyatakan Sangat Setuju (SS), dalam hal ini responden berpendapat dalam pencapaian penyelesaian tugas kerja yang diberikan secara konsisten tepat waktu dan tepat sasaran seharusnya diberi suatu reward bagi tercapainya kepuasan kerja bagi pegawai itu sendiri,karena kinerja seorang pegawai dipengaruhi oleh kepuasan kerja pegawai itu sendiri.

\section{b. Pegawai mampu menentukan dan mengatur prioritas kerja secara efektif.}

Dari hasil analisa tabel di atas dapat dilihat bahwa jawaban responden sangat signifikan yang menyatakan Sangat Setuju (SS) yaitu sebesar $57,4 \%$, pada pernyataan pegawai mampu menentukan dan mengatur prioritas kerja secara efektif, yang artinya pegawai Dinas Perhubungan Kabupaten Subang sudah memiliki kemampuan dalam menentukan dan mengatur prioritas pekerjaan secara efektif, pembagian prioritas pekerjaan sangat penting ketika pegawai dihadapkan pada tumpukan pekerjaan yang terkadang datang berbarengan terutama di waktu-waktu tertentu. Apalagi jika deadline alias batas pengerjaannya berdekatan. Kemampuan ini dibutuhkan ketika pekerjaan itu berbenturan dengan renstra organisasi itu sendiri dan dengan adanya kemampuan dalam menentukan dan mengatur prioritas kerja yang efektif membuat pegawai tahu pekrjaan mana yang didahulukan sehingga tidak ada pekerjaan yang terbengkalai. c. Pegawai mampu menggunakan waktu dengan efisien dalam melaksanakan segala tugas yang dibebankan kepadanya.

Dari hasil analisa tabel di atas dapat dilihat bahwa jawaban responden sangat signifikan yang menyatakan Sangat Setuju (SS) yaitu sebesar 53,7\%, pada pernyataan pegawai mampu menggunakan waktu dengan efisien dalam melaksanakan segala tugas yang dibebankan kepadanya. Penggunaan waktu yang efisien dalam melaksanakan pekerjaan berkaitan dengan displin kerja dan pengawasan. Artinya pegawai Dinas Perhubungan Kabupaten Subang telah disiplin dalam membagi jam kerja dan jam istirahat, ditambah dengan adanya pengawasan dari atasan yang efektif sehingga tidak ada ruang bagi pegawai yang bersantai-santai disaat ada tugas yang menumpuk yang dibebankan kepadanya. Namun tidak bisa dibantah, berdasarkan pengamatan penulis sebagai bukti nyata masih ada pegawai Dinas Perhubungan Kabupaten Subang yang tidak bisa efisien penggunaan waktu dalam melaksanakan tugas, pegawai cenderung mengobrol dibandingkan mengerjakan tugasnya. Hal demikian menyebabkan buruknya kinerja pegawai yang akan menghambat dalam pencapaian sasaran dan tujuan organisasi.

d. Pegawai dapat memelihara tempat kerja tetap teratur sesuai dengan fungsinya.

Dari hasil analisa tabel di atas dapat dilihat bahwa jawaban responden menyatakan Sangat Setuju (SS) yaitu sebesar $57,4 \%$, pada pernyataan pegawai dapat memelihara tempat kerja tetap teratur sesuai dengan fungsinya, responden berpendapat bahwa tempat kerja yang bersih, teratur sesuai fungsinya, rapih, aman dan nyaman akan mempercepat dalam memberikan pelayanan publik dan mengerjakan pekerjaan. Tempat kerja yang teratur dan bersih akan berpengaruh pada 
kinerja dan semangat kerja pegawai dan juga pemeriksaan serta pemeliharaan mesin tiap hari secara teliti dan teratur dapat mengetahui kondisi mesin setiap saat juga untuk menghindari kerusakan mesin menjadi parah di masa yang akan datang.
Menurut penulis, pegawai yang rajin dalam pemeliharan tempat kerja yang teratur dan sesuai fungsinya selayaknya diberikan reward berbentuk uang atau barang sehingga bisa memotivasi pegawai lainnya.

\section{Dimensi Kerjasama}

\section{Persentase Jawaban Responden Atas Pernyataan Dimensi Kerjasama}

$(n=54)$

\begin{tabular}{|c|l|c|c|c|c|c|}
\hline \multirow{2}{*}{ No } & \multicolumn{1}{|c|}{ Pernyataan } & \multicolumn{5}{|c|}{ Jawaban } \\
\cline { 3 - 7 } & \multicolumn{1}{|c|}{ SS } & S & R & TS & STS \\
\hline 10 & $\begin{array}{l}\text { Pegawai mampu memelihara hubungan } \\
\text { kerja yang efektif. }\end{array}$ & 66,7 & 31,5 & 1,8 & 0 & 0 \\
\hline 11 & $\begin{array}{l}\text { Pegawai dapat bekerjasama dalam tim. } \\
\text { Pegawai senantiasa memberikan bantuan } \\
\text { dan dukungan kepada orang lain. }\end{array}$ & 50,6 & 38,9 & 11,1 & 0 & 0 \\
\hline 12 & $\begin{array}{l}\text { Pegawai senantiasa mau mengakui } \\
\text { kesalahan sendiri dan mau belajar dari } \\
\text { kesalahan tersebut. }\end{array}$ & 55,6 & 27,8 & 11,1 & 0 & 5,5 \\
\hline \multicolumn{2}{|l|}{ Persentase Rata-rata } & 57 & 34,7 & 6,9 & 0 & 1,4 \\
\hline
\end{tabular}

Sumber : Hasil Pengujian, 2014

a. Pegawai mampu memelihara

hubungan kerja yang efektif.

Dari hasil analisa tabel di atas dapat dilihat bahwa jawaban responden yang menyatakan Sangat Setuju (SS) yaitu sebesar $66,7 \%$, pada pernyataan pegawai mampu memelihara hubungan kerja yang efektif, hal ini menunjukkan bahwa terciptanya suasana iklim kerja yang kondusif pada Dinas Perhubungan Kabupaten Subang, komunikasi yang efektif antara atasan dan bawahan maupun antara pegawai dan terpenuhinya kesejahteraan pegawai serta berhasil meredam konflik-konflik antar pegawai. Hubungan kerja yang efektif akan meningkatkan semangat kerja, disiplin tinggi dan bersikap baik antara atasan dan bawahan maupun dengan sesama pegawai, sehingga kinerja pegawai pun akan meningkat.

b. Pegawai dapat bekerjasama dalam tim.
Dari hasil analisa tabel di atas dapat dilihat bahwa jawaban responden pada pernyataan ini yang menyatakan Sangat Setuju (SS), yaitu sebesar 50\% namun jawaban responden pada pernyataan ini merupakan jawaban paling rendah dari pernyataan dimensi kerjasama lainnya. Hal ini menunjukkan kurangnya kerjasama tim pada pegawai di Dinas Perhubungan Kabupaten Subang yang terlihat adanya jawaban responden yaitu sebesar $11,1 \%$, yang menyatakan Ragu (R) pada pernyataan ini. Kerjasama tim di tempat kerja membantu untuk membuat komunikasi yang lebih terbuka antar pegawai, dan juga antar manajemen dan pegawai. Hal ini berjalalan dalam meningkatkan hubungan professional, pemahaman, dan kerjasama dan ini sangat tercermin dalam kualitas kerja yang dilakukan. Membangun kerjasama tim secara signifikan memberikan kontribusi terhadap motivasi pegawai dan membangun kepercayaan di antara 
pegawai, sehingga menghasilkan kinerja pegawai yang lebih baik.

c. Pegawai senantiasa memberikan bantuan dan dukungan kepada orang lain.

Dari hasil analisa tabel di atas dapat dilihat bahwa jawaban responden pada pernyataan ini yang menyatakan Sangat Setuju (SS), yaitu sebesar 55,6\%, hal ini menunjukkan pegawai Dinas Perhubunga Kabupaten senantiasa memberikan bantuan dan dukungan sosial bagi pegawai yang mengalami stress kerja sehingga nantinya pegawai tersebut dapat mengelola stress kerjanya dengan baik dan dapat memberikan dampak positif kepada para pegawai lainnya (meningkatkan kepuasan kerja, kuantitas, maupun kinerja pegawai). Dukungan sosial dapat mengurangi beban atau permasalahan yang dihadapi seseorang sehingga dapat dikatakan bahwa dukungan sosial merupakan model dukungan yang dihasilkan dari interaksi pribadi yang melibatkan salah satu atau lebih aspek emosi, penilaian, informasi dan instrumen sehingga dapat mereduksi beban yang diterima individu. d. Pegawai senantiasa mau mengakui kesalahan sendiri dan mau belajar dari kesalahan tersebut.

Dari hasil analisa tabel di atas dapat dilihat bahwa jawaban responden pada pernyataan ini yang menyatakan Sangat Setuju (SS), yaitu sebesar 55,6\%, pegawai senantiasa mau mengakui kesalahan sendiri dan mau belajar dari kesalahan tersebut, menurut responden kesalahan itu selain memberikan tantangan dan rasa yang tidak enak bisa juga memberikan peluang bagi diri kita untuk bertumbuh dan berkembang selama kita bisa mengolahnya. Kita harus mengakui kesalahan dan bertanggungjawab untuk melakukan langkah-langkah yang konstruktif, tidak perlu menghakimi diri sendiri atau menyalahkan yang lainnya. Pengakuan ini secara psikologis akan menguatkan karakter juga integritas kita. Orang lain akan lebih menghormati kita yang mau mengakui kesalahannya. Kesalahan yang dipandang bukan sesuatu yang negatif akan membawa kepada kesempatan yang tidak terduga, pembelajaran yang tertanam dengan kuat, melatih kesabaran dan kegigihan. Jika saja kita secara proaktif mau mengevaluasi dan belajar dari kesalahan tersebut.

\section{Dimensi Inisiatif}

\section{Persentase Jawaban Responden Atas Pernyataan Dimensi Inisiatif}

$(n=54)$

\begin{tabular}{|c|l|c|c|c|c|c|}
\hline \multirow{2}{*}{ No } & \multicolumn{1}{|c|}{ Pernyataan } & \multicolumn{5}{|c|}{ Jawaban } \\
\cline { 3 - 7 } 13 & $\begin{array}{l}\text { Pegawai senantiasa berinisiatif untuk } \\
\text { mengatasi setiap permasalahan dalam } \\
\text { pelaksanaan tugasnya }\end{array}$ & 44,4 & 35,2 & 20,4 & 0 & 0 \\
\hline 14 & $\begin{array}{l}\text { Pegawai telah mampu menghasilkan ide, } \\
\text { tindakan dan solusi yang inovatif. }\end{array}$ & 40,7 & 37 & 13 & 9,3 & 0 \\
\hline 15 & $\begin{array}{l}\text { Pegawai senantiasa berusaha mencari } \\
\text { tantangan baru pengembangan diri dan } \\
\text { kesempatan untuk belajar. }\end{array}$ & 33,3 & 55,6 & 3,7 & 0 & 7,4 \\
\hline 16 & $\begin{array}{l}\text { Pegawai mampu mengantisipasi dan } \\
\text { memahami masalah yang mungkin dapat } \\
\text { terjadi. }\end{array}$ & 37 & 42,6 & 20,4 & 0 & 0 \\
\hline \multicolumn{1}{|c|}{ Persentase Rata-rata } & 38,8 & 42,6 & 14,4 & 2,3 & 1,9 \\
\hline
\end{tabular}

Sumber : Hasil Pengujian, 2014 
a. Pegawai senantiasa berinisiatif untuk mengatasi setiap permasalahan dalam pelaksanaan tugasnya.

Berdasarkan hasil analisa pada tabel di atas pernyataan pegawai senantiasa berinisiatif untuk mengatasi setiap permasalahan dalam pelaksanaan tugasnya, diperoleh jawaban responden yang menyatakan Sangat Setuju (SS) yaitu sebesar $44,4 \%$, jawaban responden tidak begitu signifikan nilai yang diperoleh satu sama lainya (seperti yang tertera pada tabel diatas). Pegawai yang berinisiatif tinggi untuk mengatasi setiap permasalahan dalam menyelesaikan tugas pekerjaannya merupakan pegawai dengan latar belakang pendidikan yang tinggi dan sesuai dengan penempatan pegawai terhadap tugas pekerjaan yang diberikan agar kinerja pegawai pun akan baik. Pegawai yang memliki inisiatif yang tinggi tentu juga akan mendapat penilaian yang bagus dari pimpinan.

b. Pegawai telah mampu menghasilkan ide, tindakan dan solusi yang inovatif.

Berdasarkan hasil analisa pada tabel di atas pernyataan pegawai telah mampu menghasilkan ide, tindakan dan solusi yang inovatif, diperoleh jawaban responden yang menyatakan Sangat Setuju (SS) yaitu sebesar 40,7\%. Artinya pegawai Dinas Perhubungan Kabupaten Subang sudah cukup mampu untuk menghasilkan suatu ide, tindakan dan solusi yang inovatif terhadap permasalahan. Orang yang kreatif, pada umumnya mengetahui permasalahan dengan sangat baik dan disiplin, biasanya dapat melakukan sesuatu yang menyimpang dari cara-cara lama. Proses proses kreatifitas melibatkan adanya ideide baru, berguna, dan tidak terduga tetapi dapat diimplementasikan. Penguasaan teknologi pada organisasi tidak menjamin tercapainya tujuan organisasi apabila tidak di dukung oleh mutu SDM yang tinggi, pegawai yang mampu menghasilkan ide, tindakan dan solusi yang inovatif merupakan kesuksesan dalam keunggulan kompetitif suatu organisasi

c. Pegawai senantiasa berusaha mencari tantangan baru pengembangan diri dan kesempatan untuk belajar.

Berdasarkan hasil analisa pada tabel di atas pernyataan pegawai senantiasa berusaha mencari tantangan baru pengembangan diri dan kesempatan untuk belajar, diperoleh jawaban responden yang menyatakan Setuju (S) yaitu sebesar $55,6 \%$, pada pernyataan ini responden mayoritas menjawab pada pernyataan setuju. Hal ini menunjukkan pegawai Dinas Perhubungan Kabupaten Subang lebih tertarik mengikuti kegiatan pengembangan diri apabila ada instruksi dari atasan langsung ketimbang untuk mencari sendiri tantangan baru untuk pengembangan diri dan kesempatan untuk belajar.

Pengembangan pegawai didasarkan pada fakta bahwa seorang pegawai membutuhkan serangkaian pengetahuan, keahlian dan kemampuan yang berkembang supaya bekerja dengan baik dalam melaksanakan tugas dn fungsinya selama karirnya. Pengembangan pegawai pada dasarnya bertujuan untuk memastikan dan memelihara kemampuan pegawai sehingga memenuhi kualifikasi yang di prasyaratkan sehingga selaras dengan tujuan organisasi agar dapat tercapai sebagaimana yang telah direncanakan. Pengembangan pegawai dapat dilakukan dengan mengikuti pendidikan dan pelatihan. Dengan pegawai Dinas Perhubungan Kabupaten Subang yang berusaha mencari tantangan baru pengembangan diri dan kesempatan untuk belajar maka akan menumbuhkan kinerja yang tinggi.

d. Pegawai mampu mengantisipasi dan memahami masalah yang mungkin dapat terjadi.

Berdasarkan hasil analisa pada tabel di atas pernyataan pegawai mampu mengantisipasi dan memahami masalah 
yang mungkin dapat terjadi. diperoleh jawaban responden yang menyatakan Setuju (S) yaitu sebesar 42,6\%, hal ini menunjukkan kurangnya kemampuan pegawai Dinas Perhubungan Kabupaten Subang dalam mengantisipasi dan memahami masalah yang mungkin dapat terjadi, baik masalah yang datang dari internal maupun dari eksternal. Untuk itu untuk mengantisipasi dan memahami masalah yang akan datang maka dibutuhkan perencanaan sumber daya manusia yang merupakan proses analisis dan identifikasi tersedianya akan sumber daya manusia sehingga apabila masalah datang pegawai sudah siap memecahkan masalah dan tidak merasa asing lagi.

\section{Dimensi Tanggungjawab}

\section{Persentase Jawaban Responden Atas Pernyataan Dimensi Tanggungjawab} $(n=54)$

\begin{tabular}{|c|c|c|c|c|c|c|}
\hline \multirow{2}{*}{ No } & \multirow{2}{*}{ Pernyataan } & \multicolumn{5}{|c|}{ Jawaban } \\
\hline & & SS & $\mathrm{S}$ & $\mathrm{R}$ & TS & STS \\
\hline 17 & $\begin{array}{l}\text { Pegawai hadir dan pulang secara rutin } \\
\text { dan tepat waktu. }\end{array}$ & 24,1 & 44,4 & 5,5 & 24,1 & 1,9 \\
\hline 18 & $\begin{array}{l}\text { Pegawai senantiasa mengikuti dan } \\
\text { melaksakan instruksi-instruksi yang } \\
\text { diberikan. }\end{array}$ & 61,1 & 20,3 & 9,3 & 9,3 & 0 \\
\hline 19 & Pegawai dapat bekerja secara mandiri. & 51,9 & 29,6 & 18,5 & 0 & 0 \\
\hline 20 & $\begin{array}{l}\text { Pegawai dapat menyelesaikan tugas dan } \\
\text { memenuhi tanggungjawabnya sesuai } \\
\text { dengan batas waktu yang ditentukan. }\end{array}$ & 53,7 & 35,1 & 1,9 & 7,4 & 1,9 \\
\hline & Persentase Rata-rata & 47,7 & 32,3 & 8,8 & 10,2 & 1 \\
\hline
\end{tabular}

a. Pegawai hadir dan pulang secara rutin dan tepat waktu.

Berdasarkan hasil analisa pada tabel di atas pernyataan pegawai hadir dan pulang secara rutin dan tepat waktu, diperoleh jawaban responden yang menyatakan Setuju (S) yaitu hanya sebesar $44,4 \%$, hal ini menunjukkan pegawai Dinas Perhubungan Kabupaten Subang kurang disiplin dalam absensi pegawai, Sudah bukan rahasia umum lagi apabila ada isuisu yang beredar mengatakan bahwa pegawai negeri sipil itu santai, hanya datang dan absen saja dalam perilaku kerjanya sehari-hari. Tidak bisa dielakkan juga bahwa banyak PNS yang absensinya dititipkan pada PNS lain. Masalah titip menitip absen adalah hal yang sudah mengakar budaya bagi masyarakat Indonesia dan inilah yang wajib diselesaikan dalam rangka penegakan disiplin dalam lingkungan instansi pemerintahan.
Disiplin pada hakikatnya adalah pencerminan nilai kemandirian yang dihayati dan diamalkan oleh setiap individu dan masyarakat suatu bangsa dalam kehidupan. Untuk membina pegawai negeri sipil yang memiliki kesetiaan dan ketaatan penuh, telah dikeluarkan peraturan tentang disiplin pegawai negeri. Dalam Peraturan Pemerintah Nomor 53 Tahun 2010 telah diatur dengan jelas kewajiban yang harus ditaati dan larangan yang tidak boleh di langgar oleh setiap pegawai negeri sipil.

b. Pegawai senantiasa mengikuti dan melaksakan instruksi-instruksi yang diberikan.

Berdasarkan hasil analisa pada tabel di atas pernyataan pegawai senantiasa mengikuti dan melaksakan instruksiinstruksi yang diberikan, diperoleh jawaban responden yang menyatakan Sangat Setuju (SS) yaitu hanya sebesar $61,1 \%$, hal ini menunjukkan pegawai Dinas Perhubungan 
Kabupaten Subang sebagian besar telah tercapai kepuasan kerja yang berimplikasi kepada meningkatnya semangat kerja. Semangat kerja yang tinggi ditandai dengan gairah karyawan dalam menjalankan tugas seuai dengan perintah dan peraturan, kesetiaan pada organisasi, minat yang tinggi pada pekerjaan, dan kemauan bekerja sama dengan karyawan lain dalam mencapai tujuan organisasi.

\section{c. Pegawai dapat bekerja secara mandiri.}

Berdasarkan hasil analisa pada tabel di atas pernyataan pegawai dapat bekerja secara mandiri, diperoleh jawaban responden yang menyatakan Sangat Setuju (SS) yaitu hanya sebesar 51,9\%, hal ini menunjukan bahwa etos kerja pegwai Dinas Perhubungan Sangat tinggi, etos kerja yang tinggi tentunya rutinitas tidak akan membuat bosan, bahkan mampu meningkatkan prestasi kerjanya. Hal yang mendasari etos kerja tinggi di antaranya keinginan untuk menjunjung tinggi mutu pekerjaan, maka individu yang mempunyai etos kerja tinggi akan turut serta memberikan masukan-masukan ide di tempat bekerja dan meningkatkan kinerja.

\section{d. Pegawai dapat menyelesaikan tugas} dan memenuhi tanggungjawabnya sesuai dengan batas waktu yang ditentukan.

Berdasarkan hasil analisa pada tabel di atas pernyataan pegawai dapat menyelesaikan tugas dan memenuhi tanggungjawabnya sesuai dengan batas waktu yang ditentukan, diperoleh jawaban responden yang menyatakan Sangat Setuju (SS) yaitu hanya sebesar 53,7\%, hal ini menunjukkan bahwa pegawai dinas Perhubungan Kabupaten Subang telah memiliki kemampuan dan kecermatan dalam menyelesaikan tugas tepat waktu sebagai bukti dan tanggungjawabnya terhadap jabatan atau posisi dalam organisasi itu. Prinsip penempatan yang tepat harus dilaksanakan secara konsekuen supaya pegawai dapat menyelesaikan tugas sesuai dengan spesialisasinya/keahliannya masing-masing. The right man in the right place.

\section{Analisa Skor Keseluruhan Variabel Kinerja}

Berdasarkan data kuesioner yang tela diolah tersebut, maka berikut ini dapat disajikan ringkasan persentase frekuensi jawaban responden atas pernyataanpernyataan yang diajukan dalam kinerja pegawai Dinas Perhubungan Kabupaten Subang. Perhitungan tiap pernyataan secara keseluruhan dapat dilihat pada chart sebagai berikut :

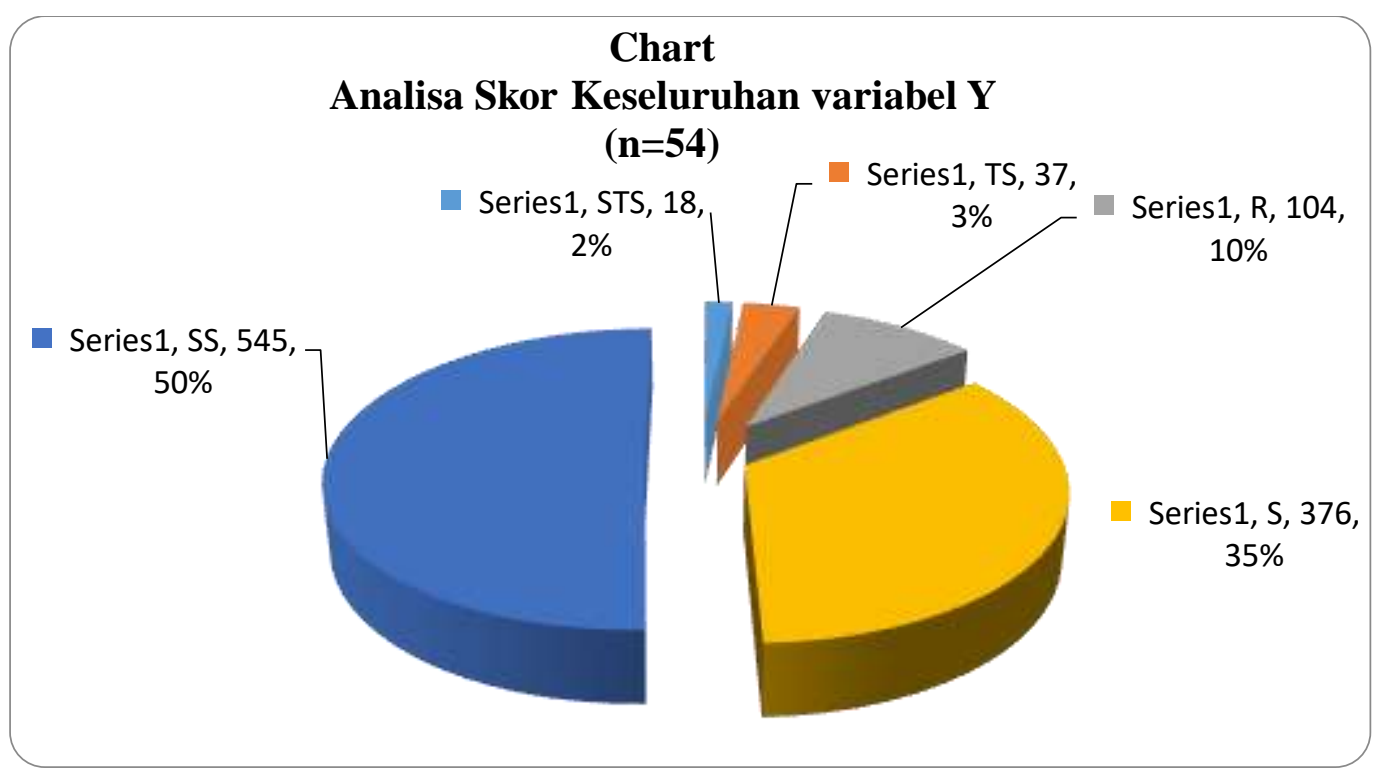


Dari chart diatas, ternyata responden menilai bahwa kinerja pegawai Dinas Perhubungan Kabupaten Subang baru sebesar $50 \%$ yang menyatakan sangat setuju (SS) atau belum sepenuhnya sesuai dengan tolak ukur kinerja menurut Yoder (dalam Sastrohadiwiryo 2005 : 236).
Untuk mengetahui pengaruh variabel kompetensi terhadap kinerja pegawai pada Dinas Perhubungan Kabupaten Subang secara simultan, dapat dilihat pada perhitungan dalam model summary, khususnya angka $\mathrm{R}$ square, sebagaimana terlihat pada tabel di bawah ini :

\section{Pengaruh Kompetensi Terhadap Kinerja Pegawai}

\begin{tabular}{|c|c|c|c|c|}
\hline \multicolumn{5}{|c|}{ Model Summaryb } \\
\hline Model & $\mathrm{R}$ & R Square & $\begin{array}{l}\text { Adjusted R } \\
\text { Square }\end{array}$ & $\begin{array}{c}\text { Std. Error of the } \\
\text { Estimate }\end{array}$ \\
\hline 1 & $.551 \mathrm{a}$ & .304 & .290 & 9.828 \\
\hline
\end{tabular}

Berdasarkan hasil perhitungan diatas, dapat diketahui bahwa koefisien determinasi ( $\mathrm{R}$ square) adalah 0.304, dimana nilai determinasi ini artinya bahwa kinerja pegawai Dinas Perhubungan Kabupaten Subang dipengaruhi oleh kompetensi adalah sebesar 30,4\%. Adapun sisanya sebesar $69,6 \%$ dipengaruhi oleh faktor lain yang tidak diteliti pada penelitian ini diantaranya gaya kepemimpinan, insentif dan pelayanan publik.

\section{SIMPULAN}

Berdasarkan hasil analisa dan pembahasan sebagaimana dijelaskan dalam bab sebelumnya, maka dapat ditarik beberapa kesimpulan sebagai berikut :

1. Kompetensi pegawai pada Dinas Perhubungan Kabupaten Subang adalah baik, namun belum optimal. Hal ini sesuai dengan total keseluruhan jawaban responden yang mayoritas menyatakan sangat setuju terhadap pernyataan variabel kompetensi yaitu hanya sebesar $58 \%$, namun masih ada beberapa indikator kompetensi yang masih rendah (kompetensi keterampilan). Untuk itu diperlukan adanya peningkatan atau pembenahan sehingga tujuan dari organisasi itu dapat tercapai yaitu memberikan pelayanan publik dengan baik, efektif dan efisien.

2. Kinerja pegawai Dinas Perhubungan Kabupaten Subang belum begitu sepenuhnya sesuai tolak ukur dalam menilai kinerja. Hal ini sesuai total jawaban keseluruhan responden yang menyatakan sangat setuju yaitu hanya sebesar $50 \%$, sisanya pada jawaban responden yang menyatakan setuju, ragu, tidak setuju dan sangat tidak setuju, sehingga dapat disimpulkan bahwa kinerja pegawai Dinas Perhubungan Kabupaten Subang masih perlu untuk ditingkatkan terutama pada dimensi inisiatif, sehingga dapat memberikan pelayanan publik yang terbaik bagi masyarakat subang.

3. Berdasarkan analisa korelasi antara kompetensi terhadap kinerja pegawai Dinas Perhubungan Kabupaten Subang terdapat hubungan yang positif searah dengan nilai $30,4 \%$ dan sisanya sebesar 69,6 dipengaruhi oleh 
faktor lain. Semakin tinggi nilai kompetensi maka semakin tinggi pula nilai kinerja yang dihasilkan.

\section{DAFTAR PUSTAKA}

Arikunto, Suharsimi. 1996. Prosedur Penelitian: Suatu Pendekatan Praktek. Jakarta: Rineka Cipta.

Hasibuan, Malayu. 2002. Manajemen Sumber Daya Manusia Edisi Revisi. Cetakan Ke-6. Jakarta: PT.Bumi Aksara.

Hutapea, Parulian dan Nurianna Thoha. 2008. Kompetensi Plus. Jakarta: PT Gramedia Pustaka Utama.

Mangkunegara, AA, Anwar Prabu. 2005. Evaluasi Kinerja SDM. Bandung: PT Refika Aditama.

Manullang.M. Dasar-Dasar Manajemen. Yogyakarta : Gadjah Mada University Press, 2005.

Moeheriono.2010. Pengukuran Kinerja Berbasis Kompetensi. Bogor : Ghalia Indonesia.

Prasetyo, Bambang, dan Lina Miftahul Jannah. 2005. Metode Penelitian Kuantitatif:Teori dan Aplikasi. Jakarta: PT Raja Grafindo Persada.
Palan, R. 2007. Competency Management. Teknik Mengimplementasikan Manajemen SDM berbasis Kompetensi untuk Meningkatkan Daya Saing Organisasi. Penerjemah: Octa Melia Jalal. Penerbit PPM. Jakarta.

Rivai, Veithzal. 2005. Performance Appraisal. Jakarta: Grafindo Persada.

Ruky, Achmad, S. 2004; Sistem Manajemen Kinerja. PT. Gramedia Pustaka Utama. Jakarta.

Siagian, Sondang P. (2006), Manajemen Sumber Daya Manusia, Cetakan ketiga belas, Bumi Aksara, Jakarta.

Sastrohadiwiryo, B. Siswanto.2003. Manajemen Tenaga Kerja Indonesia: Pendekatan Administrasi dan Operasional. Bandung:Bumi Aksara.

Singarimbun, Masri dan Sofian Effendi. 1995. Metode Penelitian Survai. Jakarta: LP3ES.

Sugiyono. 2007. Metode Penelitian Administrasi. Bandung: Alfabeta.

2010. Statistika Untuk

Penelitian. Bandung: Alfabeta. 